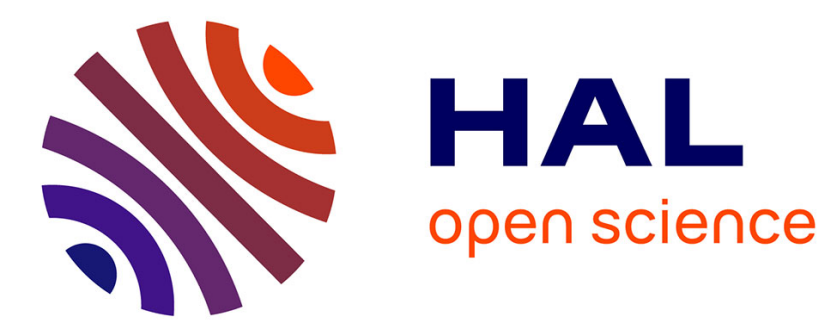

\title{
Pastoralism, sustainability, and marketing. A review
}

Workneh Tessema, Paul Ingenbleek, Hans Trijp

\section{To cite this version:}

Workneh Tessema, Paul Ingenbleek, Hans Trijp. Pastoralism, sustainability, and marketing. A review. Agronomy for Sustainable Development, 2014, 34 (1), pp.75-92. 10.1007/s13593-013-0167-4 . hal01234790

\section{HAL Id: hal-01234790 \\ https://hal.science/hal-01234790}

Submitted on 27 Nov 2015

HAL is a multi-disciplinary open access archive for the deposit and dissemination of scientific research documents, whether they are published or not. The documents may come from teaching and research institutions in France or abroad, or from public or private research centers.
L'archive ouverte pluridisciplinaire HAL, est destinée au dépôt et à la diffusion de documents scientifiques de niveau recherche, publiés ou non, émanant des établissements d'enseignement et de recherche français ou étrangers, des laboratoires publics ou privés. 


\title{
Pastoralism, sustainability, and marketing. A review
}

\author{
Workneh Kassa Tessema • Paul T. M. Ingenbleek • \\ Hans C. M. van Trijp
}

Accepted: 28 June 2013 / Published online: 26 July 2013

(C) INRA and Springer-Verlag France 2013

\begin{abstract}
Pastoralism is a highly traditional production system for livestock and livestock products. Under the surface of a seeming stability a variety of pressures of the modern time all seem to accumulate to put the sustainability of the pastoralist production system to the test. Population growth and growing demand for meat, put pressure on the natural resources used by pastoralists because the grazing lands that are saved from encroachment or conversion into arable lands, may be overexploited. Changing climatic conditions, such as frequent droughts, put even more pressure on the system. With so many challenges coming together, it is important to analyze whether pastoralism in itself can be considered a sustainable production system that in principle can cope with these challenges and thus deserves support from policy, or whether the pastoralist production system has fundamental misfit with today's challenges, in the sense that it is detrimental to the world's scarce resources. The scientific literature on pastoralism provides an important entry point to such fact finding. This article therefore analyzes 125 recent research contributions to the literature on pastoralism on their inferences as to whether pastoralism is a sustainable production system for livestock-based products. The results show substantial consensus that pastoralism is seen as a sustainable production system for livestock and livestock products (78 of the 125 studies contain sustainability inferences, of which 58 infer that the pastoral system is sustainable, while only 2 come to a negative conclusion). A total of 18
\end{abstract}

W. K. Tessema

Haramaya University, Dire Dawa, Ethiopia

P. T. M. Ingenbleek ( $\square)$

Marketing and Consumer Behaviour Group, Wageningen

University, Hollandseweg 1, 6706 KN Wageningen,

The Netherlands

e-mail: paul.ingenbleek@wur.nl

H. C. M. van Trijp

Wageningen University, Wageningen, The Netherlands studies point however at conditional factors. The main factors that can potentially explain differences in the conclusions on whether pastoralism is sustainable pertain among others to the domain of sustainability, including abiotic and biotic factors representing the planet dimension, mobility, adaptation, indigenous knowledge, institutions and population growth as people-related factors, and economic contribution as a profitrelated factor. Other factors include the ecosystem and land use types, policy instruments, constant/flexible stocking, controlled/mobile grazing, and diversification policies, as well as academic discipline, research methods and geographic focus. A quantitative test shows that consideration of adaptation, institutions and mobility are most strongly related to the sustainability inference. Such studies suggest that pastoralists that can adapt to external conditions, that are supported by effective institutions and that can exercise mobility, are more likely to behave sustainably. We argue that marketing can help to meet these conditions. Because the role of marketing has received scant attention in the context of pastoralists and because it has often been narrowly interpreted as market integration, we further explain the potential role of marketing in sustainable pastoralism. The role of marketing comes down to a strategic competence that enables pastoralists to create value for target buyers with whom they may develop economic and social relationships that can be favorable for both parties. Because it is likely to stabilize prices and generate a long-term perspective on value creation, and therefore on resource use, marketing can contribute to a pastoral system that supports people, planet, and profit.

Keywords Pastoralism · Pastoralists · Sustainable development $\cdot$ Adaptation $\cdot$ Livestock marketing

Contents

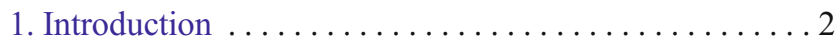

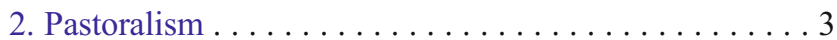


3. Potential factors influencing the sustainability of pastoralism $\ldots \ldots \ldots \ldots \ldots \ldots \ldots \ldots \ldots \ldots \ldots \ldots$

3.1. The domain of sustainability $\ldots \ldots \ldots \ldots \ldots 4$

3.2. Ecosystem and land use types $\ldots \ldots \ldots \ldots \ldots 6$

3.3. Policy instruments ...............6 6

3.4. Discipline, methods and geographic focus .....6

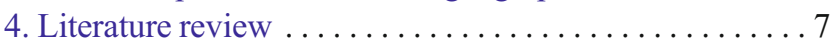

4.1. Methodology .................. 7

4.2. Descriptive results $\ldots \ldots \ldots \ldots \ldots \ldots \ldots \ldots 7$

4.3. Substantive results on sustainability inferences $\ldots 7$

5 . Role of marketing $\ldots \ldots \ldots \ldots \ldots \ldots \ldots$

6. Policy implications and future research ... . . . . 12

6.1. Policy implications ................ 12

6.2. Implications for further research $\ldots \ldots \ldots \ldots 12$

7. Conclusion .................... 13

8. Acknowledgments ................... 13

\section{Introduction}

Pastoralism is a highly traditional production system that dates back to ancient times in which the lifestyle of Biblical patriarch Abraham has much resemblance with the lifestyle of pastoralists. Also today, a large community of pastoralists still lives with herds of livestock which they move to take advantage of water and natural pasture for grazing (Koocheki and Gliessman 2005). Yet, under that surface of seeming stability, a variety of pressures of the modern time, like human population growth, rapid urbanization, the growing demand for livestock products, land use changes, and climate change (Thornton et al. 2009), all seem to accumulate to put the sustainability of the pastoralist production system to a serious test. For example, globally about $70 \%$ of the range lands in dry lands can be considered degraded, according to FAO (2006a) estimates. Pressure on the natural resources that are used by pastoralists will further increase because, as a result of population growth and changing lifestyle patterns, the demand for meat is projected to double from 229 million tons in $1999 / 2001$ to 465 million tons in 2050 (FAO 2006b). Market imperfections, such as constrained market access provide pastoralists with limited means to flexibly cope with ecological challenges (FAO 2012; Rosegrant and Thornton 2008). Next to increased demand for meat, population growth also leads to a higher population to land ratio that intensifies encroachment and the conversion of grazing lands into arable lands further threatening the livestock production of pastoralists (Steinfeld et al. 2010; Narrod et al. 2010). It also sometimes leads to overexploitation of the remaining grazing lands (Easdale and Aguiar 2012; FAO 2012). On top of these developments, changing climatic conditions, such as droughts, bring shortages in pasture and water to the livestock production of pastoralists (Thornton et al. 2009; Ericksen et al. 2012). The pressures on land and frequent droughts bring formidable challenge to the pastoralist cycle of herd building, destocking in times of drought, and a rebuilding of herds afterwards as a way to effectively sustain livestock production over time (Toulmin 1994).

With so many challenges coming together, it is important to analyze whether pastoralism in itself can be considered a sustainable production system that in principle can cope with these challenges and thus deserves support from policy, or whether the pastoralist production system has fundamental misfit with today's challenges, in the sense that it is detrimental to the world's scarce resources. The scientific literature on pastoralism provides an important entry point to such fact finding.

The debate on the sustainability of the livestock production by pastoralists has a history of several decades with important contributions from policy makers, academics, and development practitioners, especially in the aftermath of events such as the Sahelian droughts of the 1970s (Franke and Chasin 1980; Lesorogol 2005; Warren 1995). The discussion has heightened the attention of the donors such as the World Bank to fund projects that aimed to intervene on the pastoralist land use (Franke and Chasin 1980). Recently, the debate renewed in response to the continuing drought in the marginal lands of east Africa (Devereux and Scoones 2008; Scoones 2008; Sandford 2006). With the 2011 massive drought in the Horn of Africa affecting the lives of more than 12 million people (FAO 2011), the debate will probably continue in the years to come.

Opinions about the sustainability of pastoralism diverge, mainly reflecting the different ideas about the extent of overgrazing that will lead to degraded natural resources (Lamprey 1983). One position follows the Tragedy of Commons view introduced by Hardin (1968), arguing that pastoralists pursue their short-term survival at the expense of the long-term preservation of commonly shared natural resources. Building on the Tragedy of Commons thinking, extensive donor funded development projects has been invested on pastoralism to "modernize" it through private ownership of communal rangelands to avert the assumed environmental degradation (Fratkin 1997). Few of these projects however brought a positive impact on the way communal resources are used because most of them have failed to solicit the cooperation of the pastoralists (Behnke and Scoones 1993). Others have therefore called for a larger diversity of institutions to manage the commons and to explicitly incorporate the institutions of locals that have developed over many centuries (Ostrom 2000; Mwangi and Ostrom 2009). Following this view, pastoralism can be considered as an effective way of utilizing the sparse vegetation of dry lands which promises an optimal economic strategy in many areas of the world (Casimir and Rao 1998; Davies 2008). Pastoralist land use practices are then seen as an effective response to the highly variable natural environment 
in which practices can slightly change in response to changing circumstances, but the system itself remains in place (Behnke and Scoones 1993).

Although Vetter (2005) observed a growing consensus that land use by pastoralists is in principle sustainable, the direction of the literature since then is unclear. With the increased pressure on pastoralism, research efforts have also increased, both in terms of amount and diversity. Research contributions now come from a larger variety of disciplines, not only including ecology and anthropology, but increasing also from others, like geography and economics (Hatfield and Davies 2006). A fresh review of the literature on the sustainability of pastoralism is therefore both timely and important.

This article has three objectives. The first objective is to review recent research contributions on their inferences as to whether pastoralism is a sustainable production system for livestock-based products. We find substantial consensus that pastoralism is seen as a sustainable production system, although some studies point at conditional factors. The second objective is to use the research database to test quantitatively the contribution of sustainability-related variables that underpin the (un-)conditional conclusion on the sustainability of pastoralism. We find that consideration of adaptation, institutions and mobility are most strongly related to the sustainability inference. We posit that marketing can contribute to the adaptation of pastoralists, but our results confirm early work by Bailey et al. (1999) that the role of marketing as a way to improve the adaptability of pastoralists is still largely unaddressed in the discussion on the sustainability of pastoralism. Hence, the third objective of this article is to discuss how marketing can contribute to the sustainability of pastoralists by helping them to adapt.

In the remainder of this article, we first present a brief background on pastoralism and its purported sustainability. Next we explain the methodology of our study, which organizes the recent contributions to the literature according to their inferences about sustainability and examines the explanatory power of study characteristics such as the studied ecosystem and land use types, the geographic focus, research method of the studies, and the disciplines in which they were published. We then elaborate on the concept of adaptation and the role that marketing could play therein. After giving directions on how future research may address the role of marketing, we formulate conclusions and implications.

\section{Pastoralism}

Historians argue that pastoralism emerged as agriculture developed (Spooner 1971). When crop production on lands suitable for agriculture intensified, stimulated by emerging urban areas and the development of irrigation systems, lands that were too marginal for agriculture were left to the cattle
(Spooner 1971). In this sense, pastoralism is an adaptation to natural conditions by which people exploit lands such as plains, deserts, steppes, tundra, and mountains (Barfield 1997; Galaty and Johnson 1990). As an illustration, Fig. 1 shows pastoralists that let their camels drink at a well during a dry period. Nowadays, pastoralism is practiced on $25 \%$ of the world's land area (FAO 2001), and is common in Africa, Asia, the Americas, and Australia (Galaty and Johnson 1990), and a form of it based on the seasonal movement of herds still occurs in Europe (Chang and Tourtellotte 1993). Pastoralism supports about 200 million households and herds of nearly a billion head of livestock including camels, cattle, goats and sheep that account for about $10 \%$ of the world's meat production (FAO 2001).

Cohen (1974, p. 261) describes pastoralism as "a system of production devoted to gaining a livelihood from the care of large herds of animals ... based on transhumance ... an adaptation to a particular habitat: semi-arid open country or grasslands, in which hoe or digging-stick cultivation apparently cannot be sustained." Drawing on this description, we define pastoralism as a production system that involves livestock raising and uses mobility to adapt to a dry land ecology that is not suitable for sedentary crop cultivation. Other definitions sometimes restrict pastoralism to subsistence systems (Spooner 1971), but we acknowledge that pastoralists earn incomes by selling their livestock or livestock products such as milk. In addition, pastoralists may engage in crop cultivation, if the land and availability of water allow them to do so; and this makes them so called agro-pastoralists.

Unlike settled farmers, pastoralists (1) usually have access to communal grazing resources, (2) raise their livestock for direct consumption, and exchange through the market to generate cash that can provide security during droughts (Widstrand 1975), (3) locate their livestock in remote areas without advanced infrastructure or logistics systems, (4) use marginal lands where large-scale sedentary production is

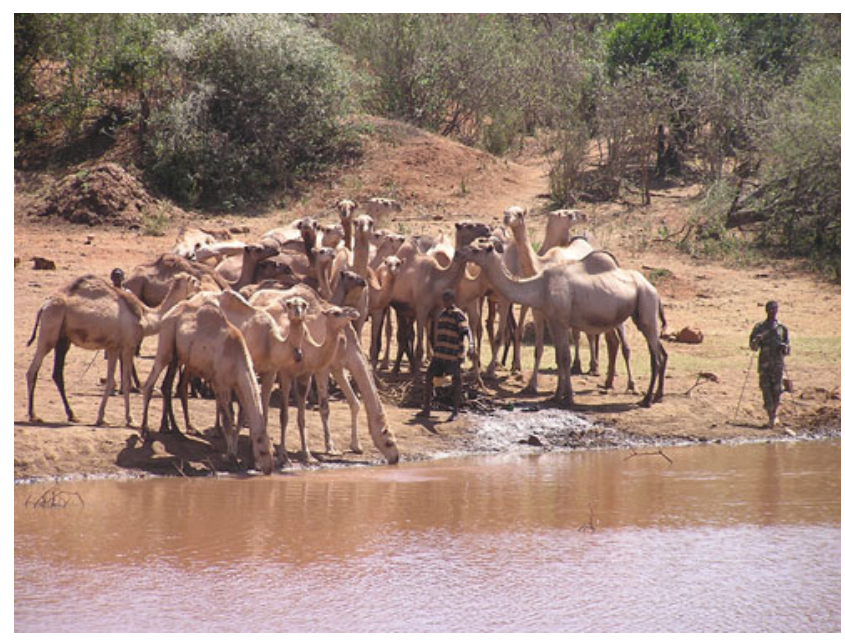

Fig. 1 Pastoralists letting their camels drink at a well during a dry period 
difficult and unsustainable (Bostedt 2005), and (5) use mobility to access pasture and water for their livestock (NiamirFuller 1999).

Because pastoralism must adapt to various physical and social conditions, it is highly diverse in terms of the type of livestock reared and strategies followed to exploit alternative livelihoods (Galaty and Johnson 1990). Dynamic social, economic, and ecological factors affect the pastoralists' daily lives, options, and decisions (Cousins et al. 2007). Temporary droughts and low market prices may induce pastoralists to pursue alternative income generating strategies that threaten their natural environment, such as producing charcoal from the scarce vegetation if they cannot sell or feed their livestock (Toulmin 1994; Devereux 2006). These events increase the ecological, socioeconomic, and political pressures on pastoralism in many parts of the world (Abule et al. 2005) and raise debates about its sustainability (Devereux and Scoones 2008; Sandford 2006).

\section{Potential factors influencing the sustainability of pastoralism}

Recent research on the sustainability of the pastoral production systems increasingly acknowledges that rangeland management in dry lands is complex and is influenced by physical, social and economic factors at different scales (Vetter 2005). The investigation of how pastoralists live with their natural ecological environment has therefore broadened so that it includes the complex dynamics of their entire environment (Sullivan 1999; Xiaogang 2005). To do justice to these conditions, the focal variable of our review, the sustainability inference that emerges from the studies on pastoralism, is operationalised at the levels: (1) pastoralism is sustainable, (2) pastoralism is not sustainable, and (3) it depends. To understand how the reviewed studies arrived at their inferences on the sustainability of pastoralism, we analyzed the studies in terms of relevant study characteristics, pertaining to the domain of sustainability, the ecosystem and land use types, the policy instruments, the academic discipline, the research method and the continent where the study was conducted (see Table 1). Although these factors may be related, their analysis will provide a deeper understanding of how important they are in guiding researchers to their sustainability inferences regarding pastoralism.

\subsection{The domain of sustainability}

Studies may arrive at different inferences on the sustainability of pastoralism, depending on how they conceptualize sustainability. Influential conceptualizations of sustainability include three themes: the planet, that is the ecological imperative to live within and maintain biodiversity, people, that is a social imperative to ensure the development of healthy and functional societies, and profit, that is an economic imperative to meet basic needs of the pastoralist community and society (Dale 2001; Brundtland 1987; Serageldin 1996). To understand how sustainability is conceptualized in the context of pastoralism, we incorporate (a) abiotic and biotic factors, which are predominantly planet-related factors, (b) mobility, adaptation, indigenous knowledge, institutions and population growth, which are predominantly people-related factors, and (c) economic contribution, which is predominantly a profit-related factor.

The nature and level of abiotic such as rainfall and biotic factors such as grazing have been linked to the sustainable land use of pastoralists (Behnke et al. 1993). This research has demonstrated that abiotic factors such as rainfall play a more important role in limiting livestock populations of pastoralists (Ellis and Swift 1988). However, biotic factors, such as grazing regime and herd size management may combine and potentially interact to disturb the system to the extent of overgrazing (Sullivan and Rohde 2002; Steinfeld et al. 2006).

Mobility is a way to make sustainable use of rangelands by pastoralists, both economically and environmentally (IFAD 2009). Mobility as an ecological rationality is a response by pastoralists to variable range production and livestock nutritional needs (Oba 2011). The sustainability of pastoralists thus depends on the ability of pastoralists to exercise livestock mobility (Fratkin and Mearns 2003). If mobility is constrained it may also lead to overgrazing and thus to a lack of sustainability (Fernandez-Gimenez and Le Febre 2006; Ostrom et al. 1999).

Adaptation refers to "the decision-making process and the set of actions undertaken to maintain the capacity to deal with current or future predicted change" (Nelson et al. 2007, p. 396). Pastoralists have shown a wide variety of adaptations to respond to the environmental and socioeconomic changes (Fratkin 1997; Galvin 2009). Adaptation is thus the flexibility in coping with changes (Smit and Wandel 2006). For example, with the increase of sedentarization, pastoralists adapt by changing their herd structure from cattle to goats (Galvin 2009). The indigenous knowledge of pastoralists is reflected in pasture use norms and herding practices, leading to a mobile land use that persisted for centuries (FernandezGimenez 2000). To this respect, the indigenous ecological knowledge of pastoralists is the foundation for their sustainable resource management (McGahey et al. 2008). Population growth potentially undermines sustainability (Lynn 2010), because it leads to fragmentation of the rangelands (IFAD 2009). In fragmented rangelands, pastoral management strategies may not be sufficient to sustain their production, potentially leading to a collapse of the system (Galvin 2009).

Formal and informal institutions can regulate sustainable grazing by organizing access to pasture and water (Fernandez- 
Table 1 Potential factors influencing sustainability inferences and their coding

\begin{tabular}{|c|c|c|}
\hline Categories & Variables & Coding scheme \\
\hline \multirow{4}{*}{$\begin{array}{l}\text { Sustainability } \\
\text { inference }\end{array}$} & Sustainable & Coded as 0 if a study considers the pastoral system sustainable \\
\hline & Not sustainable & Not included in the multivariate analyses \\
\hline & It depends & Coded as 1 if a study considers sustainability as conditioned on some, policy, measures \\
\hline & Not indicated & $\begin{array}{l}\text { Not coded for analysis if a study does not indicate a position on sustainability of the } \\
\text { pastoral system }\end{array}$ \\
\hline \multirow[t]{8}{*}{$\begin{array}{l}\text { Domain of } \\
\text { sustainability }\end{array}$} & Biotic factors & $\begin{array}{l}\text { Coded as } 1 \text { if biotic factors such as grazing by livestock are considered as causes to the } \\
\text { changes to pastoral system or vegetation, otherwise coded as } 0\end{array}$ \\
\hline & Abiotic factors & $\begin{array}{l}\text { Coded as } 1 \text { if abiotic factors such as climate and rainfall are considered as causes to the } \\
\text { changes to pastoral system or vegetation, otherwise coded as } 0 .\end{array}$ \\
\hline & Adaptation & Coded as 1 if pastoralists are considered as flexible to coping with changes, otherwise coded as 0 \\
\hline & Indigenous knowledge & $\begin{array}{l}\text { Coded as } 1 \text { if pastoralist indigenous knowledge is considered in range management, } \\
\text { otherwise coded as } 0\end{array}$ \\
\hline & Mobility & Coded as 1 if pastoralist mobility is considered in range management, otherwise coded as 0 \\
\hline & Institutions & $\begin{array}{l}\text { Coded as } 1 \text { if pastoralist traditional institutions are considered in range management, } \\
\text { otherwise coded as } 0\end{array}$ \\
\hline & Population growth & Coded as 1 if the human population growth is emphasized, otherwise coded as 0 \\
\hline & Economic contribution & $\begin{array}{l}\text { Coded as } 1 \text { if the pastoral system's economic importance to provide meat, milk, and/or } \\
\text { income is indicated, otherwise coded as } 0\end{array}$ \\
\hline \multirow[t]{3}{*}{ Ecosystem type } & Arid/semi-arid & $\begin{array}{l}\text { Coded as } 1 \text { if the ecosystem type is characterized by a lower growing period of plants, } \\
\text { otherwise coded as } 0\end{array}$ \\
\hline & Humid/sub-humid & $\begin{array}{l}\text { Coded as } 1 \text { if the ecosystem type is characterized by a longer growing period of plants, } \\
\text { otherwise coded as } 0\end{array}$ \\
\hline & $\begin{array}{l}\text { Tropical highland/ } \\
\text { temperate }\end{array}$ & $\begin{array}{l}\text { Coded as } 1 \text { if the ecosystem type is characterized by a higher daily mean temperature or } \\
\text { by a lower daily mean temperature, otherwise coded as } 0\end{array}$ \\
\hline Land use type & Pastoralism & $\begin{array}{l}\text { Coded as } 1 \text { if the land use mainly focuses on mobile livestock production, coded as } 0 \text { if } \\
\text { the land use combines livestock production with crop farming }\end{array}$ \\
\hline \multirow[t]{5}{*}{ Policy instruments } & Constant stocking & Coded as 1 if constant stocking of livestock is indicated, otherwise coded as 0 \\
\hline & Controlled grazing & Coded as 1 if controlled grazing is indicated, otherwise coded as 0 \\
\hline & Flexible stocking & Coded as 1 if flexible stocking of livestock is indicated, otherwise coded as 0 \\
\hline & Mobile grazing & Coded as 1 if mobile based grazing is indicated, otherwise coded as 0 \\
\hline & Diversification & $\begin{array}{l}\text { Coded as } 1 \text { if pastoralists are engaged in other income-generating activities in addition to } \\
\text { livestock production, otherwise coded as } 0\end{array}$ \\
\hline \multirow[t]{5}{*}{ Discipline } & Anthropology & Coded as 1 if the focus of the discipline in the study is on Anthropology, otherwise coded as 0 \\
\hline & Ecology & Coded as 1 if the focus of the discipline in the study is on Ecology, otherwise coded as 0 \\
\hline & Economics & Coded as 1 if the focus of the discipline in the study is on Economics, otherwise coded as 0 \\
\hline & Geography & Coded as 1 if the focus of the discipline in the study is on Geography, otherwise coded as 0 \\
\hline & Interdisciplinary & Coded as 1 if the focus of the discipline in the study is interdisciplinary, otherwise coded as 0 \\
\hline \multirow[t]{4}{*}{ Research method } & Quantitative & Coded as 1 if the research method used is based on quantitative techniques, otherwise coded as 0 \\
\hline & Qualitative & Coded as 1 if the research method used is based on qualitative techniques, otherwise coded as 0 \\
\hline & $\begin{array}{l}\text { Quantitative and } \\
\text { qualitative }\end{array}$ & $\begin{array}{l}\text { Coded as } 1 \text { if the research method used is based on quantitative and qualitative techniques, } \\
\text { otherwise coded as } 0\end{array}$ \\
\hline & Conceptual/review & $\begin{array}{l}\text { Coded as } 1 \text { if the research method used is based on conceptual or review techniques, otherwise } \\
\text { coded as } 0\end{array}$ \\
\hline \multirow[t]{6}{*}{ Geographic focus } & Africa & Coded as 1 if the focus of the study is in Africa, otherwise coded as 0 \\
\hline & Asia & Coded as 1 if the focus of the study is in Asia, otherwise coded as 0 \\
\hline & Global & Coded as 1 if the focus of the study is in a global context, otherwise coded as 0 \\
\hline & Australia/New Zealand & Coded as 1 if the focus of the study is in Australia/New Zealand, otherwise coded as 0 \\
\hline & Europe & Coded as 1 if the focus of the study is in Europe, otherwise coded as 0 \\
\hline & Latin America & Coded as 1 if the focus of the study is in Latin America, otherwise coded as 0 \\
\hline
\end{tabular}


Gimenez 2000; Flintan 2011). To this respect, the reciprocal arrangements that are developed by pastoralists contribute to sustainable land use (Flintan 2011). Formal institutions such as governments can, for example, influence sustainability by protecting land tenure rights of pastoralists (WISP 2008). The economic contribution that pastoralists make through their land management practices is substantial (Nelson 2012). For example, pastoralists in northern Tanzania's savannah ecosystems provide an economically valuable ecological service by conserving wildlife on their lands, which in turn helps to sustain the ecology (Nelson 2012). Generation of economic benefits to pastoralists helps for the sustainable use of the range lands (Nelson 2012; Hausner et al. 2012). But decrease in the level of income from livestock production by pastoralists can lead to the negative impacts on the range lands such as cutting trees to make charcoal for sale (Riginos et al. 2012).

\subsection{Ecosystem and land use types}

Studies conducted in different ecosystems may arrive at different sustainability inferences. Arid and semi-arid rangelands are, for example, characterized by variable rainfall and high rate of vegetation dynamics. In such ecosystems light pastoral use is possible and rain fed agriculture is usually not possible (Goodin and Northington 1985). In contrast to the arid and semi-arid ecosystem, the temperate ecosystem is a relatively productive and predictable environment in terms of forage availability and livestock production (Coughenour 2004). In terms of sustainability, the pastoralist and agropastoralist land use types have both advantages and disadvantages. For example, integration of pastoral production and cropping permits more intensive use of land than cropping or livestock husbandry alone (Bayer 1986). This is because crop residues and fallow lands offer better forage than natural range (Powell and Waters-Bayer 1984). The main disadvantage of integrating pastoral production and cropping for the pastoralists is that livestock must be closely supervised to avoid crop damage (Bayer 1986). There is also a concern to sustainability with respect to agropastoral land use because as more land is used for crop farming, pastoral land use begins to be replaced by sedentary livestock raising (Neupert 1999).

\subsection{Policy instruments}

To promote sustainability, researchers have suggested different policy instruments in terms of stocking, grazing and diversification of income. Constant (conservative) stocking strategies maintain a relatively fixed stocking rate, while flexible (opportunistic) stocking strategies vary depending on forage supply (Campbell et al. 2006; Sandford 1983). Both methods attempt to sustain the livestock production with the available forage in the range lands, but the latter give more decision authority to the pastoralists themselves. As for grazing, controlled grazing limits the number of livestock entering a grazing land, which, according to some researchers, is efficient, because it enhances productivity through fencing and better management (Iro 2009; Mueller and Green 1995). Others have stressed that mobile grazing enhances pastoralists' access to resources in climatically unpredictable environments (Nori et al. 2005; Niamir-Fuller 1999). Policies that stimulate diversification may help pastoralists to sustain their livelihood (Galvin 2009). Small-scale cropping can, for example, stabilize their income (Notenbaert et al. 2012), but it may also lead to a drop in dry season grazing areas because the most fertile lands are used to grow crops (Fratkin 2001; Notenbaert et al. 2012).

\subsection{Discipline, methods, and geographic focus}

In addition to the substantive factors discussed above, also the researchers' discipline, the research methods employed, and the geographic area of the study potentially influence the sustainability inferences from the study. As for discipline, it has been argued that anthropological studies tend to emphasize the land use strategies (Ruttan and Borgerhoff 1999), while ecologists focus more on grazing and stocking strategies (Galvin et al. 1994). In addition to these two disciplines that have contributed to research on pastoralism for a long time, we also include disciplines that have joined the debate later or have been less visible, namely economics, geography, as well as interdisciplinary studies. Different research methods can be related to the sustainable land use of pastoralists. Quantitative studies in ecology in semi-arid areas across Africa have demonstrated the key role that rainfall plays in the condition of above-ground vegetation (Behnke et al. 1993). On the other hand, the qualitative research that is based on in-depth case study analysis can show, among others, the impact of government policies such as land privatization on pastoralists (Dougill et al. 2010). We consider in our analysis categories of quantitative, qualitative, and combined quantitative and qualitative studies as well as conceptual or review studies. We categorize the geographic focus of the studies in terms of continent. Concerns about the sustainability of pastoralism have, for example, particularly been expressed pertaining to the African continent (Sandford 2006; Devereux and Scoones 2008). Because we found no studies on pastoralism in North America, we categorize the geographic focus therefore as Africa, Asia, Australia/New Zealand, Europe, Latin America, and worldwide.

In summary, the main factors that can potentially explain differences in the conclusions on whether pastoralism is sustainable pertain among others to the domain of sustainability, including abiotic and biotic factors representing the planet dimension, mobility, adaptation, indigenous knowledge, 
institutions and population growth as people-related factors, and economic contribution as a profit-related factor. In addition to these sustainability characteristics, the analysis will include the ecosystem and land use types, policy instruments, constant/flexible stocking, controlled/mobile grazing, and diversification policies, as well as academic discipline, research methods and geographic focus.

\section{Literature review}

\subsection{Methodology}

A simple search in Google Scholar for publications with the words "pastoralism" or "pastoralist" yields more than 15,000 hits for the 2005-2009 period. To identify pertinent literature, we undertook a literature search using Scopus and the Web of Science with the search terms "pastoralism and development" and "sustainability and pastoralism." Only studies published since Vetter's (2005) review were considered for the search, conducted in February 2009. In reviewing the initial search result of 553 journal articles, we excluded papers not directly related to our research, according to their title, key words, or abstract or their introductions, which indicated a few articles that did not pertain to development. Therefore, our analysis focuses on 125 papers (Table 2). We coded these contributions according to the classification scheme in Table 1.

The first author coded all the papers, and a second rater coded 40 of them to ensure intercoder reliability. We developed an initial coding scheme on the basis of prior literature and discussions between the coders after a pilot study of 10 papers. When the two coders did not agree, they discussed their differences until they reached agreement and then refined the coding scheme accordingly. If they could not reach agreement, one of the coauthors intervened. At one instance, there was disagreement about the correct interpretation on sustainability inferences between the two coders. A third coder (the second author) was called in to make a final judgment. To validate the final coding scheme an additional 30 papers were coded by two coders, resulting in a reasonably high intercoder reliability of 0.907 (Bryant and Miron 2004).

\subsection{Descriptive results}

Table 4 (lower part) shows the distribution of studies across geographic settings, academic disciplines, and research methods. This distribution reveals two insights that are worth mentioning here. First, although still dominated by ecological/ environmental approaches ( 59 out of 125 studies), research on pastoral systems appear in various academic areas. As compared to previous reviews, this indicates a growing interest of other disciplines in pastoralist production system. Second, Africa is the dominant research context accounting for 90 out of 125 studies in the research database. This must be taken into account when interpreting the policy implications, because the pastoral area in Africa is mainly savanna which is often an arid and semi arid ecological system (Homewood 2008).

From the 125 selected studies (see Table 2), 78 contained sustainability inferences. The other 47 studies were dropped for further analyses. No less than 58 , which is $74 \%$ of 78 studies, infer that the pastoral system is sustainable. Only 2 of the 78 studies, both from ecology, reach a negative conclusion about the sustainability of the system (Abule et al. 2005; Mortimore and Turner 2005). Both studies emphasize the growing human population in the range lands that impacted the mobile livestock grazing on communal lands. We also find that a substantial number of studies (18) assert that sustainability of the pastoral system is conditional. The results therefore show an almost unanimous consensus that pastoralism is not by definition unsustainable, even though some scholars apparently argue that sustainability is only reached if certain conditions are met.

The conditions to sustainability mentioned in the group of studies that inferred that sustainability is conditional, are summarized in Table 3. Studies emphasize diverse conditions, that pertain to the ecological (Hill et al. 2006; Malley et al. 2008), economic (Thornton et al. 2006), and social (Solomon et al. 2007; Richardson et al. 2007; Sternberg 2008) domains. Other studies emphasize the combination or even integration of ecological, social, and economic conditions (Boone et al. 2006; Galvin et al. 2006; Hoffman et al. 2007; Kassahun et al. 2008) that make pastoralism sustainable. For example, based on Somali pastoralists of eastern Ethiopia, Kassahun et al. (2008) indicate that sustainability requires an integrated approach that includes among others participation of pastoralists in resource conservation, and income generation. Institutions are also brought forward as a help for pastoralists to adapt to changing environments, such as land tenure systems (Solomon et al. 2007), conflict management (Haro et al. 2005), access to technologies and markets (Malley et al. 2008), secured herding contracts (Turner and Hiernaux 2008), and adaptation, sometimes referred to in comparable terms such as flexibility (Sternberg 2008; Haro et al. 2005). Multivariate analyses of the reviewed studies will show whether these and other factors relate to the sustainability inferences of the studies.

\subsection{Substantive results on sustainability inferences}

This section analyzes the 76 studies that reach a non-negative conclusion on the sustainability of the pastoral system on the factors that discriminate between the conditional and the affirmative conclusions. Column 4 in Table 4 provides the descriptive results as to how the conditional conclusion is distributed across studies that have versus have not addressed 
Table 2 Studies included in the analysis grouped by sustainability inferences

\begin{tabular}{|c|c|c|c|}
\hline Sustainable (58) & Not sustainable (2) & It depends (18) & Not indicated (47) \\
\hline $\begin{array}{l}\text { Adriansen (2006); Adriansen (2008); } \\
\text { Allsopp et al. (2007); Anderson and } \\
\text { Hoffman (2007); Anderson and } \\
\text { Centonze (2007); Angassa and Oba } \\
\text { (2008); Berhanu et al. (2007); } \\
\text { Berzborn (2007); Campbell et al. } \\
\text { (2005), Cousins et al. (2007); Curtin } \\
\text { and Western (2008); Davies (2008); } \\
\text { Davies and Bennett (2007); Davis } \\
\text { (2005); Dong et al. (2009); Hendricks } \\
\text { et al. (2007); Hobbs et al. (2008) } \\
\text { Homann et al. (2008a); Homann et al. } \\
\text { (2008b); Homewood et al. (2006); } \\
\text { Huang et al. (2007); Hunt (2008); } \\
\text { Kiunsi and Meadows (2006); } \\
\text { Kobayashi et al. (2007); Koocheki and } \\
\text { Gliessman (2005); Lesorogol (2005); } \\
\text { Little et al. (2008); McAllister et al. } \\
\text { (2008); McPeak (2005); Moritz } \\
\text { (2008); Muller et al. (2007a); Muller } \\
\text { et al. (2007b); Mwangi (2007a); } \\
\text { Mwangi and Dohrn (2008); Namgail } \\
\text { et al. (2007a); Ngugi and Conant } \\
\text { (2008); Pedersen and Benjaminsen } \\
\text { (2008); Postigo et al. (2008); Quaas } \\
\text { et al. (2007); Reeson et al. (2008); } \\
\text { Richardson et al. (2005); Roba and } \\
\text { Oba (2008); Rohde et al. (2006), } \\
\text { Samuels et al. (2007); Scholte et al. } \\
\text { (2006); Smith and McAllister (2008); } \\
\text { Tyler et al. (2007); Verlinden and } \\
\text { Kruger (2007); Vetter (2005); Vetter } \\
\text { et al. (2006); Wangui (2008); Warren } \\
\text { (2005); Wessels et al. (2007), } \\
\text { Wurzinger et al. (2008); Xiaogang } \\
\text { (2005); Yang et al. (2008); Yi et al. } \\
\text { (2008); Zhang et al. (2007) }\end{array}$ & $\begin{array}{l}\text { Abule et al. (2005); } \\
\text { Mortimore and } \\
\text { Turner (2005) }\end{array}$ & $\begin{array}{l}\text { Angassa and Oba (2007); Boone et al. } \\
\text { (2006); Borner et al. (2007); } \\
\text { Fernandez-Gimenez and Le Febre } \\
\text { (2006); Galvin et al. (2006); Gemedo- } \\
\text { Dalle et al. (2006); Haro et al. (2005); } \\
\text { Higgins et al. (2007); Hill et al. (2006); } \\
\text { Hoffman et al. (2007); Kassahun et al. } \\
\text { (2008); Malley et al. (2008); } \\
\text { Richardson et al. (2007); Solomon } \\
\text { et al. (2007); Sternberg (2008); } \\
\text { Thornton et al. (2006); Turner and } \\
\text { Hiernaux (2008); Unruh (2005) }\end{array}$ & $\begin{array}{l}\text { Abebe et al. (2008); Adriansen and } \\
\text { Nielsen (2005); Barrett et al. (2005); } \\
\text { Barrett et al. (2006a); Barrett et al. } \\
\text { (2006b); Bellemare and Barrett } \\
\text { (2006); Benjaminsen (2008); Blaikie } \\
\text { (2006); Boone et al. (2007); Bostedt } \\
\text { (2005); Briske et al. (2005); Britz and } \\
\text { Ward (2007); Campbell et al. (2006); } \\
\text { Doss et al. (2008); Gill (2005); } \\
\text { Hoffman and Rohde (2007); Kabubo- } \\
\text { Mariara (2005); King (2008); } \\
\text { Kyeyamwa et al. (2008); La Rovere } \\
\text { et al. (2005); Lebert and Rohde } \\
\text { (2007); Lybbert et al. (2007); Madulu } \\
\text { (2005); McAllister et al. (2006); } \\
\text { McCarthy (2007); McPeak (2006a); } \\
\text { McPeak and Doss (2006); Miehe } \\
\text { et al. (2008); Milligan and Binns } \\
\text { (2007); Morton (2007); Moyo et al. } \\
\text { (2008); Muchiru et al. (2008); } \\
\text { Mwangi (2007b); Namgail et al. } \\
\text { (2007b); Niyogi et al. (2007); } \\
\text { O’Connor and Kuyler (2009); Oba } \\
\text { et al. (2008); Ogutu et al. (2005); } \\
\text { Okayasu et al. (2007); Retzer (2006); } \\
\text { Sandford and Scoones (2006); } \\
\text { Slegers and Stroosnijder (2008); } \\
\text { Smet and Ward (2005); Thornes } \\
\text { (2007); Thornton et al. (2007); Turner } \\
\text { et al. (2007); Upton (2008) }\end{array}$ \\
\hline
\end{tabular}

the particular issue (organized into sustainability domain, policy instrument, and ecosystem and land use type). The results indicate that variables on the domain of sustainability have relatively equal distributions across studies that have addressed the issue versus those that haven't. As such, this category allows potentially for strong statistical conclusions.

The table also shows that policy instruments have often been ignored in existing studies, with the exception of mobile grazing and, to a lesser extent, diversification. With regard to ecosystems and land use types, the available research is clearly dominated by (semi-) arid regions, with much less attention to tropical highland and (sub-) humid contexts. With regard to the disciplines, ecologists are clearly the main suppliers to the literature. Qualitative research is the most frequently applied method. Most studies had a geographic focus on Africa.

We next conducted multivariate analyses per block of independent variables, i.e. domain of sustainability, policy instruments, ecosystem and land use types, discipline, research method, and geographic focus, relating to the sustainability inferences to examine any relations. We use the following logistic regression model for each block of variables.

$\operatorname{Logit}(p)=\mathrm{C}+\beta 1 \mathrm{X} 1+\ldots+\beta \mathrm{nXn}$

Where $p$ is the probability that a study reaches a conditional rather than unconditional positive conclusion on sustainability of the pastoral system; $C$ is a constant; $\beta$ s are the parameter estimates (reported in column 2 of Table 4); and $X_{1}-X_{n}$ denote dummies for predictor variables pertaining to the specific group of variables relating to sustainability inferences. Because the highest Variance Inflation Factor in these models is 2.860 for ecology in the discipline variables category, multicollinearity is unlikely to have influenced the findings (Hair et al. 1995).

With the exception of the domain of sustainability, for none of the sets of variables we find statistical support that 
Table 3 Overview of conditions indicated for sustainable pastoralism

\begin{tabular}{|c|c|c|}
\hline Condition & Description & References \\
\hline Adaptation & $\begin{array}{l}\text { Flexibility to adjust to changes in social, } \\
\text { market economic, and ecological such as rainfall factors. }\end{array}$ & $\begin{array}{l}\text { Sternberg (2008); Kassahun et al. (2008); } \\
\text { Angassa and Oba (2007) }\end{array}$ \\
\hline Management strategies & $\begin{array}{l}\text { Techniques followed in livestock production and use of } \\
\text { natural resources such as flexible stocking and mobility }\end{array}$ & $\begin{array}{l}\text { Thornton et al. (2006); Richardson et al. (2007); } \\
\text { Borner et al. (2007); Higgins et al. (2007); } \\
\text { Turner and Hiernaux (2008) }\end{array}$ \\
\hline Indigenous knowledge & $\begin{array}{l}\text { Traditional knowledge about rangeland, water management, } \\
\text { and grazing reserves }\end{array}$ & $\begin{array}{l}\text { Angassa and Oba (2007); Gemedo-Dalle et al. } \\
\text { (2006); Solomon et al. (2007); } \\
\text { Fernandez-Gimenez and Le Febre (2006) }\end{array}$ \\
\hline Institutions & $\begin{array}{l}\text { Customary and legal land tenure systems, conflict management, } \\
\text { security of herding contracts, access to markets and technologies }\end{array}$ & $\begin{array}{l}\text { Solomon et al. (2007); Fernandez-Gimenez and } \\
\text { Le Febre (2006); Haro et al. (2005); Malley et al. } \\
\text { (2008); Unruh (2005) }\end{array}$ \\
\hline Integrated approach & $\begin{array}{l}\text { Combining two or more activities together such as resource } \\
\text { conservation and income generation, and land use } \\
\text { for livestock production and cultivation }\end{array}$ & $\begin{array}{l}\text { Kassahun et al. (2008); Boone et al. (2006); } \\
\text { Galvin et al. (2006); Hill et al. (2006); } \\
\text { Hoffman et al. (2007) }\end{array}$ \\
\hline
\end{tabular}

addressing these factors in the research significantly changes the odds of reaching a conditional conclusion. This is largely due to the unequal distribution of studies that have versus have not addressed the issue. The results show that studies that consider adaptation and the role of institutions are more likely to reach a positive rather than conditional conclusion to their inference to sustainability of pastoralism. Studies that pay research attention to mobility are more likely to reach a conditional conclusion on sustainability of the pastoral system. When we add control variables to the equation, such as the ecosystem and land use types, research methods, disciplines, and continents, the effects remain significant.

In summary, the quantitative analysis confirms the consensus among research contributions that the pastoral system is sustainable, but also hints towards three important factors on which this sustainability inference may depend: mobility, adaptation and institutions. We explored these studies in more detail for their more nuanced conclusions. The eight studies that include adaptation and arrive at a conditional conclusion indicate that pastoralist production practices are based on adaptive ways to secure their livelihood in unpredictable environment. They further argue that failure to incorporate the practices and strategies of the pastoralists in policy reduces their adaptation. Without pastoralists being able to adapt, pastoralism is not sustainable. Studies on mobility that arrive at a conditional conclusion $(n=12)$ indicate that the mobility of pastoralists is increasingly restricted due to land tenure changes that favor ranching, sub-dividing and privatizing communal lands, sedentarization and crop farming. These studies see mobility as a necessary condition for pastoralism to be sustainable because it provides pastoralists with the freedom to adapt; thus roughly echoing the logic underlying the studies that focus on adaptation. Studies on institutions that arrive at a conditional conclusion $(n=8)$ indicate that institutions that promote sedentarization are overshadowing the customary pastoral institutions that support sustainable practices. In line with the studies on adaptation they therefore emphasize the indigenous ability of pastoralists to adapt to the changing conditions. The adaptation to changing resource inputs, in the case of pastoralists due to changing ecologic and climatic conditions; the active influence of output markets to facilitate such adaptation, including the role of institutions, are central to the marketing philosophy. As such, insights from marketing theory may contribute to a better understanding of when and why the pastoral system is sustainable and how marketing-based strategies can be implemented and facilitated to enhance sustainability. As marketing's contribution has largely gone unaddressed in this research domain (Charter et al. 2002), we reflect on this potential role in the next section.

\section{Role of marketing}

Marketing refers to "the activity, set of institutions, and processes for creating, communicating, delivering, and exchanging offerings that have value for customers, clients, partners, and society at large" (American Marketing Association 2007). From this perspective, marketing is a competence that enables entities like companies or pastoralists to create value for target buyers with whom they may develop economic and social relationships that can be favorable for both parties. Central to the marketing concept is the strategic inclination; managing the market exchange process such that the right product is delivered at the right time in the right place, generating an appropriate price. Adaptation, mobility, and institutions are in that respect important determinants of strategic marketing of pastoralists.

Rather than marketing, prior research has studied the market behaviors of pastoralists along the lines of market integration. Market integration refers to the amount of agricultural 
Table 4 Distribution of studies along the inferences "sustainable" and "it depends"

\begin{tabular}{|c|c|c|c|c|c|c|}
\hline \multirow[t]{2}{*}{ Variables } & \multirow[t]{2}{*}{ Multivariate B } & \multirow[t]{2}{*}{$\begin{array}{l}\text { \# studies that addresses } \\
\text { the variable }(n=125)\end{array}$} & \multicolumn{2}{|c|}{$\begin{array}{l}\text { \# studies that (doesn't) address } \\
\text { the variable from the studies } \\
\text { that reach a conditional }(n=76)\end{array}$} & \multicolumn{2}{|c|}{$\begin{array}{l}\text { Proportion of the studies } \\
\text { that reaches a conditional } \\
\text { conclusion from the studies } \\
\text { that address the variable }\end{array}$} \\
\hline & & & $\begin{array}{l}\text { Variable not } \\
\text { addressed }\end{array}$ & $\begin{array}{l}\text { Variable } \\
\text { addressed }\end{array}$ & $\begin{array}{l}\text { Variable not } \\
\text { addressed }\end{array}$ & $\begin{array}{l}\text { Variable } \\
\text { addressed }\end{array}$ \\
\hline \multicolumn{7}{|l|}{ Domain of sustainability } \\
\hline Biotic & 0.142 & 58 & $8 / 35$ & $10 / 41$ & 0.23 & 0.24 \\
\hline Abiotic & 0.177 & 68 & $6 / 30$ & $12 / 46$ & 0.20 & 0.26 \\
\hline Adaptation & $-2.019^{\mathrm{a}}$ & 58 & $10 / 33$ & $8 / 43$ & 0.30 & 0.19 \\
\hline Indigenous knowledge & 1.010 & 37 & $10 / 47$ & $8 / 29$ & 0.21 & 0.28 \\
\hline Mobility & $1.447^{\mathrm{b}}$ & 60 & $6 / 30$ & $12 / 46$ & 0.20 & 0.26 \\
\hline Institutions & $-1.161^{\mathrm{b}}$ & 64 & $10 / 34$ & $8 / 42$ & 0.29 & 0.19 \\
\hline Population growth & 0.190 & 47 & $10 / 42$ & $8 / 34$ & 0.24 & 0.24 \\
\hline Economic contribution & 0.472 & 52 & $8 / 36$ & $10 / 40$ & 0.22 & 0.25 \\
\hline \multicolumn{7}{|l|}{ Policy instruments } \\
\hline Constant stocking & 0.198 & 5 & $17 / 73$ & $1 / 3$ & 0.23 & 0.33 \\
\hline Flexible stocking & -0.771 & 18 & $16 / 62$ & $2 / 14$ & 0.26 & 0.14 \\
\hline Controlled grazing & -20.479 & 9 & $18 / 70$ & $0 / 06$ & 0.26 & 0.00 \\
\hline Mobile grazing & -0.528 & 74 & $6 / 23$ & $12 / 53$ & 0.26 & 0.23 \\
\hline Diversification & 0.515 & 31 & $11 / 55$ & $7 / 21$ & 0.20 & 0.33 \\
\hline \multicolumn{7}{|l|}{ Ecosystem and land use types } \\
\hline (semi-)arid & 0.272 & 103 & $3 / 9$ & $15 / 67$ & 0.33 & 0.22 \\
\hline Tropical highland $^{\mathrm{c}}$ & & 12 & $17 / 71$ & $1 / 5$ & 0.24 & 0.20 \\
\hline (sub-)humid & 1.396 & 10 & $16 / 72$ & $2 / 4$ & 0.22 & 0.50 \\
\hline (agro-)pastoral & -1.065 & 125 & $4 / 9$ & $14 / 67$ & 0.44 & 0.21 \\
\hline \multicolumn{7}{|l|}{ Discipline } \\
\hline Anthropology & -0.847 & 10 & $17 / 68$ & $1 / 8$ & 0.25 & 0.13 \\
\hline Ecology & -0.105 & 59 & $9 / 37$ & $9 / 39$ & 0.24 & 0.23 \\
\hline Economics & 0.251 & 26 & $15 / 66$ & $3 / 10$ & 0.23 & 0.30 \\
\hline Geography & 0.118 & 17 & $15 / 65$ & $3 / 11$ & 0.23 & 0.27 \\
\hline Interdisciplinary $^{c}$ & & 13 & $16 / 68$ & $2 / 8$ & 0.24 & 0.25 \\
\hline \multicolumn{7}{|l|}{ Research method } \\
\hline Quantitative & -0.087 & 23 & $15 / 64$ & $3 / 12$ & 0.23 & 0.25 \\
\hline Qualitative & -0.205 & 55 & $10 / 41$ & $8 / 35$ & 0.24 & 0.23 \\
\hline Quantitative and qualitative & -0.288 & 18 & $15 / 62$ & $3 / 14$ & 0.24 & 0.21 \\
\hline Conceptual/review ${ }^{\mathrm{c}}$ & & 29 & $14 / 61$ & $4 / 15$ & 0.23 & 0.27 \\
\hline \multicolumn{7}{|l|}{ Geographic focus } \\
\hline Africa $^{\mathrm{c}}$ & & 90 & $4 / 21$ & $14 / 55$ & 0.19 & 0.25 \\
\hline Asia & -1.005 & 13 & $17 / 67$ & $1 / 9$ & 0.25 & 0.11 \\
\hline Global & 0.669 & 10 & $16 / 71$ & $2 / 5$ & 0.23 & 0.40 \\
\hline Australia/New Zealand & -0.312 & 8 & $17 / 71$ & $1 / 5$ & 0.24 & 0.20 \\
\hline Europe & -20.128 & 3 & $18 / 75$ & $0 / 1$ & 0.24 & 0.00 \\
\hline Latin America & -20.128 & 1 & $18 / 75$ & $0 / 1$ & 0.24 & 0.00 \\
\hline
\end{tabular}

${ }^{\mathrm{a}} \mathrm{p}<0.05,{ }^{\mathrm{b}} \mathrm{p}<0.1,{ }^{\mathrm{c}}$ Parameter is not estimated because the variables in the focal category are mutually exclusive

produce that is offered to the market versus the amount that is consumed by the household (Timmer 1997). Because livestock is the most important economic output of pastoralists as compared to livestock products like milk and leather (Davies and Hatfield 2007), market integration of pastoralists can be seen as the number or volume of livestock sold and bought in the market (Tessema 2012). Grounded in the literature on transaction cost economics, market integration is likely to 
increase with a decrease of transactions costs. Costs of information search and negotiation that are often mentioned as barriers to market integration (Hatfield and Davies 2006; Scoones 1994) are, for example, likely to decrease with the establishment of formal market places where pastoralists with their livestock are brought in contact with buyers (Barrett et al. 2006c; IFAD 2010). Because such interventions currently rank high on many policy agendas, several authors witness a trend towards increased market integration of pastoralists from the Horn of Africa (Mahamoud 2012; Catley et al. 2012; Desta et al. 2006).

Several positive consequences for sustainability have been ascribed to market integration. By producing for a market, pastoralists enter the cash economy which logically leads to more specialization and efficiency. Based on historical data on the livestock marketing of Gabra pastoralists in Kenya of 50 years, McPeak (2006b) finds, for example, that increased market integration has allowed pastoralists to meet their subsistence needs with smaller herds. Pastoralists may also increase their quality of life, for examples by buying cereal food and other consumer products like medicines for themselves and for their livestock, or by sending their children to school, and through financial investments (Adriansen 2006; Homewood 2008; Riseth and Vatn 2009). Also the ecology potentially benefits from market integration because pastoralists can destock livestock in times of drought and buy after the drought (Turner and Williams 2002; McPeak and Little 2006). This helps pastoralists to adjust their livestock population to available feed resources (Verbeke et al. 2009), making their production more sustainable against changes in climatic conditions (Adriansen 2008). The cash generated from selling a part of their herd further enables pastoralists to purchase fodder during dry period for their remaining livestock (Blench 2001).

Yet, market integration may also create a situation in which these positive consequences for sustainability turn negative. When an upcoming drought demands that more pastoralists bring a larger share of their herd to the market, prices are likely to drop (Holtzman and Kulibaba 1994). Pastoralists therefore have less money to buy cereal foods and other consumer products. Moreover, the prices for these goods will increase as a consequence of the suddenly increasing demand (Kerven 1992; Swift 2011; Lybbert et al. 2000). When pastoralists subsequently decide to refrain from selling, the ecology may be structurally damaged. Market integration is therefore a concept that provides at best only a part of the market-based solution to make pastoralism sustainable.

While market integration is a necessary condition for marketing, the two concepts are fundamentally different in that marketing emphasizes a strategic, anticipatory, approach. This strategic component is reflected in the market orientation concept, which captures a seller's understanding of what the market wants at what moment in time. In a behavioral sense, market orientation refers to the generation and sharing of market information pertaining to current and future customers and competitors (Kohli and Jaworski 1990). Ingenbleek et al. (2013) apply the concept of market orientation to pastoralists in the Borana and Awash Valley regions of Ethiopia. They find that not market integration but an orientation towards customers is the strongest predictor of livelihood performance. Their study also implies that market orientation can not only be learnt from modern management books, but can also be learnt by experience (Kerven 1992; Homewood 2008).

When pastoralists manage to understand the specific wants and needs of their target buyers, they are likely to be rewarded by customers through willingness to pay and loyalty in terms of repeated purchases. Pastoralists can attain this, for example, by using specific breeds and raising the livestock in particular ways so that they meet certain quality criteria. Superior insights in customer wants enable pastoralists to increase the quality of their livestock as it is perceived by their target buyers, through for example feeding and fattening practices. Such practices differentiate the livestock that pastoralists offer and reduce the level of commodity competition, characterized by uniform quality and low prices, especially when the supply increases in times of drought. A study by Radeny et al. (2006) found that the type and quality of livestock that pastoralists supply to the market can influence the price that they receive. Davies et al. (2010) note that marketing has a growing influence on herd composition. Market-oriented pastoralists are therefore more likely to sell a larger share of their herd when climatic conditions demand them to do so. In a semiexperimental study, Tessema (2012) finds evidence that market-oriented pastoralists indeed intend to do so.

By offering livestock and livestock products that cater the needs of target customers, more durable relationships between buyers and sellers develop, that are characterized by both economic and social aspects. This in turn facilitates the integration between parties within marketing channels. More integrated chains can develop concerted efforts to solve a sudden increase in supply. Downstream players can stimulate demand by developing new market connections and promotion campaigns. Dissemination of communication technology, like mobile phones, can help pastoralists to become an integral part of such supply chains (Little 2012). Besides contributing to ecological sustainability, marketing therefore potentially decreases poverty among pastoralists and may help to improve the fair distribution of rents in the channel. The pastoralist literature has in that respect acknowledged that improving marketing skills may increase the competitiveness of pastoralists (Hatfield and Davies 2006; Kyeyamwa et al. 2008) and strengthen their position in the emerging livestock chains (Coppock et al. 2005; Catley et al. 2012; Aklilu 2008).

Because it can contribute to livelihoods as well as ecological sustainability, marketing favors an integrated approach 
in pastoralist policy (Boone et al. 2006; Kassahun et al. 2008). Institutions can in that respect make the marketing efforts of pastoralists and other channel members more effective. Public policy is an important force to establish new institutions. According to Nori et al. (2005), marketing has, however, seldom been used in policy making for pastoralists. Musemwa et al. (2008) argue that most of the projects that involve collective action groups end up in removing production bottle necks in disregard of the marketing factors. As an exception, Desta et al. (2006) find that assistance in basic education, information, and market relationships, increases pastoralists' livestock sales for export.

In summary, because the role of marketing has received scant attention in the context of pastoralists and because it has often been narrowly interpreted as market integration, we further explained the potential role of marketing in sustainable pastoralism. This role of marketing comes down to a strategic competence that enables pastoralists to create value for target buyers with whom they may develop economic and social relationships that can be favorable for both parties. Because it is likely to stabilize prices and generate a long-term perspective on value creation; and therefore on resource use, marketing can contribute to a pastoral system that supports people, planet and profit. As explained in the next section, also policy makers may approach their policies from a marketing viewpoint.

\section{Policy implications and future research}

\subsection{Policy implications}

Supporting the development of a true market orientation competence should be an important policy objective. Developing a market orientation requires the support of clan members (in particular elders), as well as the sufficient availability of market information on customer wants. The adoption of market standards may further facilitate the transactions between pastoralists and their (potential) buyers. The formation of producer groups may help pastoralists to increase their level of market orientation and take advantage of market opportunities (Markelova and Mwangi 2010). Collective marketing can enable pastoralists to meet quality and safety standards and enable the supply of the quantities demanded by larger buyers (Thorp et al. 2005). Enhancing the market orientation of pastoralists may also require an increased awareness among the clan elders who may consider livestock selling as a possible threat to the security of their clan members. To this respect, clan elders need to understand the possible benefits of advance livestock destocking in order to restock after the drought. Younger generations, growing up with market opportunities may think more commercially about the value of their livestock than older generations, thus gradually changing traditional cultural values (Marin 2008) and gradually replacing subsistence lifestyles by lifestyles in which consumer products are more prominent (Casciarri 2009).

Market orientation should however not be equated by setting short-term sales objectives. It is the strategic inclination of market orientation that may help to secure a sustainable use of natural resources. Increases in the market participation of pastoralists can lead to higher herd productivity (Zander 2011). At the same time pastoralists might be constrained from selecting productive breeds, such as those producing more milk, because they also take into account the ecological tolerance of the breed types. For example, pastoralists may be forced to take into account the hardiness of the livestock type to tolerate forage shortages rather than their productivity (Desta et al. 2011). Policy may facilitate this trade-off through breeding programs, research and/or improving the forage conditions.

While supporting the market orientation of pastoralists, policy measures are required to minimize any undesired lifestyle changes, such as increased alcohol consumption, that may accompany increased market orientation of pastoralists. A higher market orientation could potentially ruin pastoralists' lifestyles as well as their livelihood level unless the benefits that pastoralists gain from a higher price are properly channeled for saving and further investments. In other words: long term value creation requires the appropriate institutions. Developing financial and insurance markets could therefore be a complementary endeavor that policy makers need to consider (von Braun 1995).

\subsection{Implications for further research}

While market orientation is an important concept to connect marketing thinking more strongly with the literature on pastoralism, the marketing literature than the market orientation concept only may have more to offer to the sustainability of pastoralists. Future research may explore, for example, the potential benefits of relationship marketing concepts (Berry 1983; Gronroos 1995; Sheth and Parvatiyar 1995), concepts from the knowledge-based view of the firm (Grant 1996), and customer satisfaction models (Szymanski and Henard 2001).

Research could also be directed on identifying the effects of market orientation on changes in the lifestyle of pastoralists. In this regard, sociological research might be conducted to investigate relationships between the higher market orientation of pastoralists and other market integration types with respect to the changes in lifestyle. The outcomes from this type of research could be helpful in designing polices that aim to enhance market orientation while being abreast to pastoralists' culture and lifestyles.

Finally, more in general, interdisciplinary research appears necessary to deal with the research challenges ahead. Input from the social sciences can reveal the adaptation 
exercises of pastoralists, while ecologists test their actual impact on natural conditions. Economists then are needed to understand whether market conditions stimulate adaptation to sustainable pastoralism or promote unsustainable practices. As the environments that pastoralists face grow complex and dynamic, all elements of sustainability (ecological, social, and economic) should be addressed in their full breadth to help pastoralists function in a more sustainable manner. Addressing pastoralism from a perspective that covers all elements of sustainability, therefore, can enhance wise use of the natural resources, pastoralists' livelihood, and their contribution to the growing demand for animal protein. The marketing concept may be a continuous source of inspiration in these efforts as the strategic creation of customer value has proven to be a basis to strengthen sustainable development of pastoralist system.

\section{Conclusion}

Pastoralism is not necessarily unsustainable, but, according to the literature in recent years, its sustainability depends on adaptation, mobility and institutions. Marketing can help pastoralists to adapt through strategic selling and buying to strengthen their livelihood and to adapt to natural conditions that demand either destocking because of drought or allow restocking because of rain. In that respect, strategic marketing with a central view on the creation of customer value can contribute to economic, social and ecological sustainability at the same time.

Acknowledgments Financial support for this study was obtained through a grant to the first author by the joint project NPT-ETH-152 between the Netherlands Organization for International Cooperation in Higher Education and Research (Nuffic) and Haramaya University of Ethiopia.

\section{References}

Abebe D, Adrian C, Andy C, Yacob A, Gedlu M, Yodit G (2008) Impact of a commercial destocking relief intervention in Moyale district, southern Ethiopia. Disasters 32:167-189

Abule E, Snyman HA, Smit GN (2005) Comparisons of pastoralists perceptions about rangeland resource utilization in the middle Awash Valley of Ethiopia. J Environ Manage 75:21-35

Adriansen HK (2006) Continuity and change in pastoral livelihoods of Senegalese Fulani. Agric Human Values 23:215-229. doi:10.1007/ s10460-005-6108-3

Adriansen HK (2008) Understanding pastoral mobility: the case of Senegalese Fulani. Geogr J 174:207-222

Adriansen HK, Nielsen TT (2005) The geography of pastoral mobility: Spatiotemporal analysis of GPS data from Sahelian Senegal. GeoJournal 64:177-188

Aklilu Y (2008) Livestock marketing in Kenya and Ethiopia: A review of policies and practice. Feinstein International Center, Addis Ababa
Allsopp N, Catherine L, Laure M, Debeaudoin M, Igshaan S (2007) Environmental perceptions and practices of livestock keepers on the Namaqualand commons challenge conventional rangeland management. J Arid Environ 70:740-754

American Marketing Association (2007) Definition of marketing. http:// www.marketingpower.com/AboutAMA/Pages/DefinitionofMarketing. aspx. Accessed 28 December 2011.

Anderson S, Centonze R (2007) Property rights and the management of animal genetic resources. World Dev 35:1529-1541

Anderson P, Hoffman MT (2007) The impacts of sustained heavy grazing on plant diversity and composition in lowland and upland habitats across the Kamiesberg mountain range in the Succulent Karoo, South Africa. J Arid Environ 70:686-700

Angassa A, Oba G (2007) Relating long-term rainfall variability to cattle population dynamics in communal rangelands and a government ranch in southern Ethiopia. Agric Syst 94:715-725

Angassa A, Oba G (2008) Herder perceptions on impacts of range enclosures, crop farming, fire-ban and bush-encroachment on the rangelands of Borana, southern Ethiopia. Hum Ecol 36:201-215

Bailey D.V., Barrett C.B., Little P.D., Chabari F. (1999) Livestock markets and risk management among east African pastoralists: a review and research agenda.

Barfield T (1997) Pastoral Nomads. In: Barfield T (ed) Dictionary of anthropology. Blackwell, Oxford, UK

Barrett CB, Lee DR, McPeak J (2005) Institutional arrangements for rural poverty reduction and resource conservation. World Dev 33:193-197

Barrett CB, Marenya P, McPeak J et al (2006a) Welfare dynamics in rural Kenya and Madagascar. J Dev Stud 42:248-277

Barrett CB, Michael RC, Peter DL (2006b) Understanding and reducing persistent poverty in Africa: introduction to a special issue. J Dev Stud 42:167-177

Barrett CB, Bellemare MF, Osterloh SM (2006c) Household-level livestock marketing behaviour among northern Kenyan and southern Ethiopian pastoralists. In: McPeak J, Peter DL (eds) Pastoral livestock marketing in eastern Africa: research and policy challenges. ITDG, Warwickshire, UK

Bayer W. (1986) Agropastoral herding practices and grazing behaviour of cattle in the subhumid zone of Nigeria.

Behnke RH, Scoones I (1993) Rethinking range ecology: implications for rangeland management in Africa. In: Behnke RH, Scoones I, Kerven C (eds) Range ecology at disequilibrium, new models of natural variability and pastoral adaptation in African savannas. Overseas Development Institute, London

Behnke RH, Scoones I, Kerven C (eds) (1993) Range ecology at disequilibrium. New models of natural variability and pastoral adaptation in African Savannas. Overseas Development Institute, London, London

Bellemare MF, Barrett CB (2006) An ordered Tobit model of market participation: evidence from Kenya and Ethiopia. Amer J Agr Econ 88:324-337

Benjaminsen TA (2008) Does supply-induced scarcity drive violent conflicts in the African Sahel? The case of the Tuareg rebellion in northern Mali. J Peace Res 45:819-836

Berhanu W, David C, Bichaka F (2007) Diversification and livelihood sustainability in a semi-arid environment: a case study from southern Ethiopia. J Dev Stud 43:871-889

Berry LL (1983) Relationship marketing. In: Berry LL, Shostack L, Upah G (eds) In emerging perspectives on services marketing. American Marketing Association, Chicago, IL, pp 25-28

Berzborn S (2007) The household economy of pastoralists and wagelaborers in the Richtersveld, south Africa. J Arid Environ 70:672-685

Blaikie P (2006) Is small really beautiful? Community-based natural resource management in Malawi and Botswana. World Dev 34:1942-1957

Blench R (2001) You can't go home again: pastoralism in the new millennium. Overseas Development Institute, London 
Boone RB, Galvin KA, Thornton PK, Swift DM, Coughenour MB (2006) Cultivation and conservation in Ngorongoro conservation area, Tanzania. Hum Ecol 34:809-828. doi:0.1007/s10745-0069031-3

Boone RB, Lackett JM, Galvin KA, Ojima DS, Tucker IIICJ (2007) Links and broken chains: evidence of human-caused changes in land cover in remotely sensed images. Environ Sci Policy 10:135-149

Borner J, Higgin SI, Kantelhardt J, Scheiter S (2007) Rainfall or price variability: what determines rangeland management decisions? A simulation-optimization approach to South African savannas. Agric Econ 37:189-200

Bostedt G (2005) Pastoralist economic behavior: empirical results from reindeer herders in northern Sweden. J Agric Resour Econ 30:381-396

Briske DD, Fuhlendorf SD, Smeins FE (2005) State-and-transition models, thresholds and rangeland health: a synthesis of ecological concepts and perspectives. Rangeland Ecol Manage 58:1-10

Britz ML, Ward D (2007) Dynamics of woody vegetation in a semi-arid savanna, with a focus on bush encroachment. Afr J Range Forage Sci 24:131-140

Brundtland GH (ed) (1987) Our common future: world commission on environment and development. Oxford University Press, Oxford, UK

Bryant J, Miron D (2004) Theory and research in mass communication. J Commun 54:662-704

Campbell DJ, David PL, Thomas AS, Edna EW (2005) Multiple methods in the study of driving forces of land use and land cover change: a case study of SE Kajiado district, Kenya. Hum Ecol 33:763-794

Campbell BM, Gordon IJ, Luckert MK, Petheram L, Vetter S (2006) In search of optimal stocking regimes in semi-arid grazing lands: one size does not fit all. Ecol Econ 60:75-85. doi:10.1016/j.ecolecon. 2006.05.010

Casciarri B (2009) Between market logic and communal practices: Pastoral nomad groups and globalization in contemporary Sudan (Case studies from central and western Sudan). Nomadic Peoples 13:69-91

Casimir M, Rao A (1998) Sustainable herd management and the tragedy of no man's land: an analysis of west Himalayan pastures using remote sensing techniques. Hum Ecol 26:113-134

Catley A., Lind J., Scoones I. (Eds.) (2012) Development at the margins: Pathways of change in the Horn of Africa. Earthscan.

Chang C, Tourtellotte PA (1993) Ethno-archaeological survey of pastoral transhumance sites in the Grevena Region, Greece. J Field Archaeol 20:249-264. doi:10.1179/009346993791549192

Charter M, Peattie K, Ottman J, Polonsky MJ (2002) Marketing and sustainability. Centre for Business, Farnham, Surrey England

Cohen YA (1974) Man in adaptation: the cultural present, 2nd edn. Aldine, Chicago

Coppock D.L., Desta S., Gebru G., Tezera S. (2005) Linking pastoralists and exporters in a livestock marketing chain: Recent experiences from Ethiopia. ENVS Faculty Publications. Paper 200.

Coughenour M (2004) The Ellis paradigm-humans, herbivores and rangeland systems. J Range Forage Sci 21:191-200

Cousins B, Hoffman MT, Allsopp N, Rohde RF (2007) A synthesis of sociological and biological perspectives on sustainable land use in Namaqualand. J Arid Environ 70:834-846. doi:10.1016/j. jaridenv.2007.04.002

Curtin C, Western D (2008) Grasslands, people, and conservation: over the horizon learning exchanges between African and American pastoralists. Conserv Biol 22:870-877

Dale A (2001) At the edge. Sustainable Development in the 21st Century. University of British Columbia Press, Vancouver

Davies J (2008) Turning the tide: enabling sustainable development for Africa's mobile pastoralists. Nat Resour Forum 32:175-184. doi: $10.1111 /$ j.1477-8947.2008.00190.x

Davies J, Bennett R (2007) Livelihood adaptation to risk: Constraints and opportunities for pastoral development in Ethiopia's Afar region. J Dev Stud 43:490-511. doi:10.1080/00220380701204422
Davies J, Hatfield R (2007) The economics of mobile pastoralism: a global summary. Nomadic Peoples 11:91-116. doi:10.3167/np.2007. 110106

Davies J, Niamir-Fuller M, Kerven C, Bauer K (2010) Extensive livestock production in transition: the future of sustainable pastoralism. In: Steinfeld H, Mooney HA, Schneider F, Neville LE (eds) Livestock in a changing landscape, volume 1, drivers, consequences, and responses. Island Press, Washington, DC

Davis DK (2005) Indigenous knowledge and the desertification debate: problematizing expert knowledge in North Africa. Geoforum 36:509-524. doi:10.1016/j.geoforum.2004.08.003

Desta S., Gebru G., Tezera S., Coppock D.L. (2006) Linking pastoralists and exporters in a livestock marketing chain: recent experiences from Ethiopia. In: McPeak J., Little P.D. (Eds.), Pastoral livestock marketing in east Africa: Research and policy challenges. Intermediate Technology Publications

Desta T, Ayalew W, Hegde B (2011) Breed and trait preferences of Sheko cattle keepers in southwestern Ethiopia. Trop Anim Health Prod 43:851-856

Devereux S (2006) Vulnerable livelihoods in Somali Region. IDS Research Report, Ethiopia, 57

Devereux S., Scoones I. (2008) The crisis of pastoralism? Future agricultures discussion paper 003. Brighton, UK: Future Agricultures Consortium at the Institute of Development Studies. http://www. future-agricultures.org/e-debate/pastoralism-in-crisis. Accessed 5 November 2012.

Dong SK, Lassoie J, Shrestha KK, Yan ZL, Sharma E, Pariya D (2009) Institutional development for sustainable rangeland resource and ecosystem management in mountainous areas of northern Nepal. J Environ Manage 90:994-1003

Doss C, McPeak J, Barrett CB (2008) Interpersonal, inter-temporal and spatial variation in risk perceptions: evidence from east Africa. World Dev 36:1453-1468

Dougill AJ, Fraser ED, Reed MS (2010) Anticipating vulnerability to climate change in dryland pastoral systems: using dynamic systems models for the Kalahari. Ecol Soc 15:17

Easdale MH, Aguiar MR (2012) Regional forage production assessment in arid and semi-arid rangelands - a step towards socialecological analysis. J Arid Environ 83:35-44

Ellis J, Swift DM (1988) Stability of African pastoral ecosystems. J Range Manage 41:450-459

Ericksen P., de Leeuw J., Thornton P., Said M., Herrero M., Notenbaert A. (2012) Climate change in sub-Saharan Africa. In: Catley A., Lind J., Scoones I. (Eds.), Development at the Margins: Pathways of change in the Horn of Africa, Earthscan.

FAO (2001) Pastoralism new millennium. FAO Animal Production and Health Paper 150.

FAO (2006a) Livestock's long shadow. In: Steinfeld H, Gerber P, Wassenaar T, Castel V, Rosales M, de Haan C (eds) Environmental issues and options. FAO, Rome, p 390

FAO (2006b) World agriculture: towards 2030/2050. Interim report, Global Perspective Studies Unit. Food and Agriculture Organization of the United Nations, Rome, Italy

FAO (2011). Rome emergency meeting rallies to aid Horn of Africa. http://www.fao.org/news/story/en/item/82543/icode/. Accessed 15 December 2011.

FAO (2012) Livestock sector development for poverty reduction: an economic and policy perspective-Livestock's many virtues, by Otte J., Costales A., Dijkman J., Pica-Ciamarra U., Robinson T., Ahuja V., Ly and C., Roland-Holst D., Rome, pp. 161

Fernandez-Gimenez ME (2000) The role of Mongolian nomadic pastoralists' ecological knowledge in rangeland management. Ecol Appl 10:1318-1326

Fernandez-Gimenez E, Le Febre S (2006) Mobility in pastoral systems: Dynamic flux or down-ward trend? Intern J Sust Devt World Ecol 13:341-362 
Flintan F (2011) Broken lands: broken lives? Causes, processes and impacts of land fragmentation in the rangelands of Ethiopia. Kenya and Uganda For (Regional Learning and Advocacy Programme), Nairobi

Franke RW, Chasin BH (1980) Seeds of famine: Ecological destruction and the development dilemma in the West African Sahel. Rowman \& Allanheld, New Jersey

Fratkin E (1997) Pastoralism: governance and development issues. Annu Rev Anthropol 26:235-261. doi:10.1146/annurev.anthro.26.1.235

Fratkin E (2001) East African pastoralism in transition: Maasai, Boran, and Rendille Cases. Afr Stud Rev 44:1-25

Fratkin E, Mearns R (2003) Sustainability and pastoral livelihoods: Lessons from east African Maasai and Mongolia. Hum Organ 62:112-122

Galaty JG, Johnson D (eds) (1990) The world of pastoralism: herding systems in comparative perspective. Guilford Press, London

Galvin KA (2009) Transitions: pastoralists living with change. Annu Rev Anthropol 38:185-198. doi:10.1146/annurev-anthro-091908-164442

Galvin K.A., Coppock D.L., Leslie P.W. (1994) Diet, nutrition, and the pastoral strategy. In: Fratkin E., Galvin K., Roth E. (Eds.), African pastoralist systems. Lynne Rienner

Galvin KA, Thornton PK, de Pinho J, Sutherland J, Boone RB (2006) Integrated modeling and its potential for resolving conflicts between conservation and people in the rangelands of east Africa. Hum Ecol 34:155-183. doi:10.1007/s10745-006-9012-6

Gemedo-Dalle T, Isselstein J, Maass BL (2006) Indigenous ecological knowledge of Borana pastoralists in southern Ethiopia and current challenges. Intern J Sust Devt World Ecol 13:113-130. doi:10. 1080/13504500609469666

Gill N (2005) Life and death in Australian 'heartlands': pastoralism, ecology and rethinking the outback. J Rural Stud 21:39-53

Goodin JR, Northington DK (1985) Plant resources of arid and semiarid lands, a global perspective. Academic, Orlando (Florida)

Grant RM (1996) Toward a knowledge-based theory of the firm. Strateg Manag J 17:109-122

Gronroos C (1995) Relationship marketing: the strategy continuum. J Acad Mark Sci 23:252-254

Hair JF, Anderson R, Tatham R, Black W (1995) Multivariate data analysis. Prentice-Hall, New Jersey

Hardin G (1968) The tragedy of the commons. Science 162:1243-1248

Haro G, Doyo G, McPeak JG (2005) Linkages between community, environmental and conflict management: experiences from Northern Kenya. World Dev 33:285-299. doi:10.1.1.133.8836

Hatfield R., Davies J. (2006) Global review of the economics of pastoralism. World initiative for sustainable pastoralism. www. iucn.org/en/news/archive/. Accessed 6 December 2007

Hausner VH, Fauchald P, Jernsletten J (2012) Community-based management: under what conditions do Sa'mi pastoralists manage pastures sustainably? PLoS One 7:1-99. doi:10.1371/journal. pone. 0051187

Hendricks H, Bond WJ, Midgley JJ, Novellie PA (2007) Biodiversity conservation and pastoralism-reducing herd size in a communal livestock production system in Richtersveld National Park. J Arid Environ 70:718-727

Higgins SI, Kantelhardt J, Scheiter S, Boerner J (2007) Sustainable management of extensively managed savanna rangelands. Ecol Econ 62:102-114

Hill MJ, Lesslie R, Donohue R, Houlder P, Holloway J, Smith J, Ritman $\mathrm{K}$ (2006) Multi-criteria assessment of tensions in resource use at continental scale: a proof of concept with Australian rangelands. Environ Manag 37:712-731

Hobbs NT, Galvin KA, Stokes CJ et al (2008) Fragmentation of rangelands: implications for humans, animals, and landscapes. $\mathrm{N}$ Glob Environ Chang 18:776-785

Hoffman M, Rohde R (2007) From pastoralism to tourism: the historical impact of changing land use practices in Namaqualand. J Arid Environ 70:641-658
Hoffman MT, Allsopp MN, Rohde RF (2007) Sustainable land use in Namaqualand, South Africa: key issues in an interdisciplinary debate. J Arid Environ 70:561-569. doi:10.1016/j.jaridenv.2006.11.021

Holtzman JS, Kulibaba NP (1994) Livestock marketing in pastoral Africa: Policies to increase competitiveness, efficiency and flexibility. In: Scoones I (ed) Living with uncertainty. New directions in pastoral development in Africa. Intermediate Technology Publications Ltd., London

Homann S, Rischkowsky B, Steinbach J (2008a) The effect of development interventions on the use of indigenous range management strategies in the Borana lowlands in Ethiopia. Land degrad develop 19:368-387. doi:10.1002/ldr.845

Homann S, Rischkowsky B, Steinbach J, Kirk M, Mathias E (2008b) Towards endogenous livestock development: Borana pastoralists' responses to environmental and institutional changes. Hum Ecol 36:503-520

Homewood K (2008) Ecology of African pastoralist societies. Ohio University Press, Athens

Homewood K, Trench P, Randall S, Lynen G, Bishop B (2006) Livestock health and socio-economic impacts of a veterinary intervention in Maasailand: infection and treatment vaccine against east coast fever. Agric Syst 89:248-271. doi:10.1016/j.agsy.2005.09.004

Huang D, Wang K, Wu WL (2007) Problems and strategies for sustainable development of farming and animal husbandry in the agropastoral transition zone in northern China. Int J Sustainable Devel World Ecol 14:391-399. doi:10.1080/13504500709469739

Hunt LP (2008) Safe pasture utilisation rates as a grazing management tool in extensively grazed tropical savannas of northern Australia. Rangel J 30:305-315. doi:10.1071/RJ07058

IFAD (2009) Livestock and pastoralists. Livestock Thematic Papers Tools for project design. http://www.ifad.org/lrkm/factsheet/ Pastoralists.pdf. Accessed 12 November 2012.

IFAD (2010) Value chains, linking producers to the markets. International Fund for Agricultural Development. Livestock Thematic Papers Tools for project design. www.ifad.org/lrkm/factsheet/valuechains. pdf. Accessed 12 November 2012.

Ingenbleek PTM, Tessema WK, van Trijp HCM (2013) Doing field research in subsistence markets, with an application to market orientation in the context of Ethiopian pastoralists. Int J Res Mark 30:83-97

Iro I. (2009) Fulani herding system. http://www.gamji.com/fulani4.htm. Accessed 5 December 2012.

Kabubo-Mariara J (2005) Herders response to acute land pressure under changing property rights: some insights from Kajiado district, Kenya. Environ Dev Econ 9:67-85

Kassahun A, Snyman HA, Smit GN (2008) Impact of rangeland degradation on the pastoral production systems, livelihoods and perceptions of the Somali pastoralists in Eastern Ethiopia. J Arid Environ 72:1265-1281. doi:10.1016/j.jaridenv.2008.01.002

Kerven C (1992) Customary commerce: a historical reassessment of pastoral livestock marketing in Africa. Overseas Development Institute, London

King EG (2008) Facilitative effects of Aloe secundiflora shrubs in degraded semi-arid rangelands in Kenya. J Arid Environ 72:358-369

Kiunsi RB, Meadows M (2006) Assessing land degradation in the Monduli district, northern Tanzania. Land degrad Develop 17:509-525

Kobayashi M, Howitt RE, Jarvis LS, Laca EA (2007) Stochastic rangeland use under capital constraints. Am J Agric Econ 89:805-817. doi:10.1111/j.1467-8276.2007.00981.x

Kohli AK, Jaworski BJ (1990) Market orientation: the construct, research propositions, and managerial implications. J Mark 54:1-18

Koocheki A, Gliessman S (2005) Pastoral nomadism, a sustainable system for grazing land management in arid areas. J Sustain Agric 25:113-131

Kyeyamwa H, Speelman S, Van Huylenbroeck G, Opuda-Asibo J, Verbeke W (2008) Raising off-take from cattle grazed on natural 
rangelands in sub-Saharan Africa: a transaction cost economics approach. Agric Econ 39:63-72

La Rovere R, Hiernaux P, Van Keulen H, Schiere J, Szonyi J (2005) Coevolutionary scenarios of intensification and privatization of resource use in rural communities of south-western Niger. Agric Syst 83:251-276

Lamprey H (1983) In: Bourliere F (ed) Pastoralism yesterday and today: the overgrazing problem. Tropical Savannas Elsevier, Amsterdam, pp 643-666

Lebert T, Rohde R (2007) Land reform and the new elite: exclusion of the poor from communal land in Namaqualand, South Africa. J Arid Environ 70:818-833

Lesorogol CK (2005) Privatizing pastoral lands: economic and normative outcomes in Kenya. World Dev 33:1959-1978. doi:10.1016/j. worlddev.2005.05.008

Little PD (2012) Reflections on the future of pastoralism in the horn of Africa. In: Catley A, Lind J, Scoones I (eds) Development at the margins: pathways of change in the Horn of Africa. Routledge, London

Little PD, McPeak J, Barrett CB, Kristjanson P (2008) Challenging orthodoxies: understanding poverty in pastoral areas of east Africa. Dev Chang 39:587-611

Lybbert T, Barrett CB, Desta S, Coppock DL (2000) Pastoral risk and wealth differentiated herd accumulation patterns in southern Ethiopia. Abstract for selected paper from the Annual Meeting of the American Agricultural Economics Association, Tampa Florida

Lybbert T, Barrett CB, McPeak J, Winnie K (2007) Bayesian herders: updating of rainfall beliefs in response to external forecasts. World Dev 35:480-497

Lynn S. (2010) The pastoral to agro-pastoral transition in Tanzania: Human adaptation in an ecosystem context. www.economics-of-cc-in-tanzania. org/images/StacyLynnPastoralism. Accessed 5 June 2011.

Madulu N (2005) Environment, poverty and health linkages in the Wami river basin: a search for sustainable water resource management. Phys Chem Earth 30:950-960

Mahamoud A.H. (2012) Pastoralists' innovative responses to new camel export market opportunities on the Kenya/Ethiopia borderlands. In: Catley A., Lind J., Scoones I. (Eds.), Development at the Margins: Pathways of Change in the Horn of Africa. Earthscan

Malley Z, Taeb M, Matsumoto T, Takeya H (2008) Linking perceived land and water resources degradation, scarcity and livelihood conflicts in southwestern Tanzania: implications for sustainable rural livelihood. Environ Dev Sustain 10:349-372

Marin A (2008) Between cash cows and golden calves: adaptations of Mongolian pastoralism in the 'Age of the market'. Nomadic Peoples 12:75-101

Markelova H, Mwangi E (2010) Collective action for smallholder market access: evidence and implications for Africa. Rev Policy Res 27:621-640

McAllister RR, Gordon IJ, Janssen MA, Abel N (2006) Pastoralists' responses to variation of rangeland resources in time and pace. Ecol Appl 16:572-583

McAllister RJ, Cheers B, Darbas T et al (2008) Social networks in arid Australia: a review of concepts and evidence. Rangel J 30:167176. doi:10.1071/RJ07040

McCarthy N (2007) Climate variability and flexibility in resource access: the case of past-oral mobility in Northern Kenya. Environ Dev Econ 12:403-421

McGahey D, Davies J, Barrow E (2008) Pastoralism as conservation in the Horn of Africa: effective policies for conservation outcomes in the drylands of Eastern Africa. Ann Arid Zones 46:353-377

McPeak J (2005) Individual and collective rationality in pastoral production: evidence from northern Kenya. Hum Ecol 33:171-197. doi:10.1007/s10745-005-2431-Y

McPeak J (2006a) Confronting the risk of asset loss: what role do livestock transfers in northern Kenya play? J Dev Econ 81:415-437
McPeak JG (2006b) Livestock marketing in Marsabit district, Kenya, over the past fifty years. In: McPeak JG, Little PD (eds) Pastoral livestock marketing in east Africa: research and policy challenges. Intermediate Technology Publications, Rugby

McPeak J, Doss C (2006) Are household production decisions cooperative? Evidence on pastoral migration and milk sales from northern Kenya. Amer J Agr Econ 88:525-541

McPeak JG, Little PD (eds) (2006) Pastoral livestock marketing in east Africa: research and policy challenges. Intermediate Technology Publications, Rugby

Miehe G, Miehe S, Kaiser K, Jianquan L, Zhao X (2008) Status and dynamics of the Kobresia pygmaea ecosystem on the Tibetan Plateau. Ambio 37:272-279

Milligan S, Binns T (2007) Crisis in policy, policy in crisis: understanding environmental discourse and resource use conflict in northern Nigeria. Geogr J 173:143-156

Moritz M (2008) Competing paradigms in pastoral development? A perspective from the Far North of Cameroon. World Dev 36:22432254. doi:10.1016/j.worlddev.2007.10.015

Mortimore M, Turner B (2005) Does the Sahelian smallholder's management of woodland, farm trees, rangeland support the hypothesis of human-induced desertification? J Arid Environ 63:567-595

Morton J (2007) The impact of climate change on smallholder and subsistence agriculture. PNAS 104:19680-19685

Moyo B, Dube S, Lesoli M, Masika P (2008) Communal area grazing strategies: institutions and traditional practices. Afr J Range Forage Sci 25:47-54. doi:10.2989/AJRFS.2008.25.2.2.481

Muchiru AN, Western DJ, Reid RS (2008) The role of abandoned pastoral settlements in the dynamics of African large herbivore communities. J Arid Environ 72:940-952. doi:10.1016/j.jaridenv. 2007.11.012

Mueller J.P., Green J.T. (1995) Controlled grazing, forage-livestock systems. West Virginia University Extension Service

Muller B, Anja L, Karin F, Michael B, Christian W (2007a) Learning from local knowledge: modeling the pastoral nomadic range management of the Himba, Namibia. Ecol Appl 17:1857-1875

Muller BK, Frank K, Wissel C (2007b) Relevance of rest periods in non-equilibrium rangeland systems a modelling analysis. Agric Syst 92:295-317

Musemwa L, Mushunje A, Chimonyo M, Fraser G, Mapiye C, Muchenje V (2008) Nguni cattle marketing constraints and opportunities in the communal areas of South Africa: review. Afr J Agric Res 3:239-245

Mwangi E (2007a) The puzzle of group ranch subdivision in Kenya's Maasailand. Dev Chang 38:889-910

Mwangi E (2007b) Subdividing the commons: distributional conflict in the transition from collective to individual property rights in Kenya's Maasailand. World Dev 35:815-834. doi:10.1016/j.worlddev.2006. 09.012

Mwangi E, Dohrn S (2008) Securing access to dry lands resources for multiple users in Africa: a review of recent research. Land Use Policy 25:240-248. doi:10.1016/j.landusepol.2007.07.002

Mwangi E, Ostrom E (2009) Top-down solutions: looking up from east Africa's range lands. Environment 51:34-44

Namgail T, Fox JL, Bhatnagar YV (2007a) Habitat shift and time budget of the Tibetan argali: the influence of livestock grazing. Ecol Res 22:25-31

Namgail T, Bhatnagar YV, Mishra C, Bagchi S (2007b) Pastoral nomads of the Indian Changthang: production system, land use and socioeconomic changes. Hum Ecol 35:497-504

Narrod C, Tiongco M, Delgado C (2010) socioeconomic implications of the livestock industrialization process: How will smallholders fare? In: Steinfeld H, Mooney HA, Schneider F (eds) Livestock in a changing landscape, vol. 2. Island Press, Washington D.C

Nelson F (2012) Natural conservationists? Evaluating the impact of pastoralist land use practices on Tanzania's wildlife economy. 
Pastoralism: Research, Policy and Practice 2:15. doi:10.1186/ 2041-7136-2-15

Nelson DR, Adger W, Brown K (2007) Adaptation to environmental change: contributions of a resilience framework. Annu Rev Environ Resour 32:395-419

Neupert RF (1999) Population, nomadic pastoralism and the environment in the Mongolian Plateau. Popul Environ 20:413-442

Ngugi MK, Conant RT (2008) Ecological and social characterization of key resource areas in Kenyan rangelands. J Arid Environ 72:820835. doi:10.1016/j.jaridenv.2007.09.009

Niamir-Fuller M (ed) (1999) Managing mobility in African rangelands: the legitimization of transhumance. Intermediate Technology Publications, London

Niyogi D, Mark K, Chris J, Colin R (2007) Stream communities along a catchment land-use gradient: subsidy-stress responses to pastoral development. Environ Manage 39:213-225

Nori M., Switze J., Crawford A, (2005) Herding on the brink: towards a global survey of pastoral communities and conflict. IISD.

Notenbaert A, Davies J, De Leeuw J, Said M, Herrero M, Manzano P, Waithaka M, Aboud A, Omondi S (2012) Policies in support of pastoralism and biodiversity in the heterogeneous drylands of East Africa. Pastoralism: Res, Policy Prac 2:14. doi:10.1186/2041-7136-2-14

O'Connor T, Kuyler P (2009) Impact of land use on the biodiversity integrity of the moist sub-biome of the grassland biome South Africa. J Environ Manag 90:384-395

Oba G. (2011) Mobility and the sustainability of the pastoral production system in Africa: perspectives of contrasting paradigms.

Oba G, Sjaastad E, Roba H (2008) Framework for participatory assessments and implementation of global environmental conventions at the community level. Land degrad develop 19:65-76

Ogutu J, Nina B, Robin R (2005) The effects of pastoralism and protection on the density and distribution of carnivores and their prey in the Mara ecosystem of Kenya. J ZoolLond 265:281-293

Okayasu T, Muto M, Jamsran U, Takeuchi K (2007) Spatially heterogeneous impacts on rangeland after social system change in Mongolia. Land Degrad Develop 18:555-566

Ostrom E (2000) The danger of self-evident truths. Political Sci Polit $33: 33-44$

Ostrom E, Burger J, Field C, Policasky D (1999) Revisiting the commons: local lessons, global challenges. Science 9(284):278-282. doi:10.1126/science.284.5412.278

Pedersen J, Benjaminsen T (2008) One leg or two? Food security and pastoralism in the northern Sahel. Hum Ecol 36:43-57. doi:10. 1007/s10745-007-9136-3

Postigo JC, Young KR, Crews KA (2008) Change and continuity in a pastoralist community in the high Peruvian Andes. Hum Ecol 36:535-551

Powell J.M., Waters-Bayer A. (1984) Interactions between livestock husbandry and cropping in a West African savanna. Paper presented at the International Savanna Symposium, Brisbane, 28-31 May

Quaas MF, Baumgartner S, Becker C, Frank K, Muller B (2007) Uncertainty and sustainability in the management of rangelands. Ecol Econ 62:251-266

Radeny M, Kristjanson P, Ruto E, Scarpa R, Wakhungu J (2006) Determinants of cattle prices in southern Kenya: implications for breed conservation and pastoral marketing strategies. In: McPeak J, Little PD (eds) Pastoral livestock marketing in east Africa: research and policy challenges. Intermediate Technology Publications, Rugby

Reeson AF, McAllister R, Whitten S, Gordon I, Nicholas M, McDouall S (2008) The agistment market in the northern Australian rangelands: failings and opportunities. Rangel J 30:283-289. doi:10.1071/ RJ06042

Retzer V (2006) Impacts of grazing and rainfall variability on the dynamics of a Sahelian rangeland revisited (Hein, 2006); New insights from old data. J Arid Environ 67:157-164
Richardson FD, Hahn BD, Hoffman MT (2005) On the dynamics of grazing systems in the semi-arid succulent Karoo: the relevance of equilibrium and non-equilibrium concepts to the sustainability of semi-arid pastoral systems. Ecol Model 187:491-512. doi:10. 1016/j.ecolmodel.2005.02.001

Richardson FD, Hahn BD, Hoffman MT (2007) Modelling the sustainability and productivity of pastoral systems in the communal areas of Namaqualand. J Arid Environ 70:701-717. doi:10.1016/j. jaridenv.2006.07.013

Riginos C, Porensky L, Veblen K et al (2012) Lessons on the relationship between livestock husbandry and biodiversity from the Kenya long-term exclosure experiment. Pastoralism: Res, Policy Prac 2:10. doi:10.1186/2041-7136-2-10

Riseth J, Vatn A (2009) Modernization and pasture degradation: a comparative study of two Sámi reindeer pasture regions in Norway. Land Economics 85:87-106. doi:10.3368/le.85.1.87

Roba H, Oba G (2008) Integration of herder knowledge and ecological methods for land degradation assessment around sedentary settlements in a sub-humid zone in northern Kenya, Intern. J Sust Devt World Ecol 15:251-264. doi:10.3843/SusDev.15.3:8

Rohde R, Moleele N, Mphale M, Allsopp N, Chanda R, Hoffman MT, Magole L, Young E (2006) Dynamics of grazing policy and practice: environmental and social impacts in three communal areas of southern Africa. Enviro Sci Policy 9:302-316. doi:10. 1016/j.envsci.2005.11.009

Rosegrant M, Thornton PK (2008) Do higher meat and milk prices adversely affect poor people? id21 insights 72:4

Ruttan L, Borgerhoff MM (1999) Are East African pastoralists truly conservationists? Curr Anthropol 40:621-652

Samuels M, Allsopp N, Knight R (2007) Patterns of resource use by livestock during and after drought on the commons of Namaqualand, South Africa. J Arid Environ 70:728-739

Sandford S (1983) Management of pastoral development in the Third World. Wiley, Chichester

Sandford S. (2006) Too many people, too few livestock: The crisis affecting pastoralists in the greater Horn of Africa. http://www. future-agricultures.org/e-debate/pastoralism-in-crisis. Accessed 1 December 2011.

Sandford S, Scoones I (2006) Opportunistic and conservative pastoral strategies: some economic arguments. Ecol Econ 58:1-16

Scholte P, Saidou K, Mark M, Herbert P (2006) Pastoralist responses to floodplain rehabilitation in north Cameroon. Hum Ecol 34:27-51. doi:10.1007/s10745-005-9001-1

Scoones I (ed) (1994) Living with uncertainty: new directions in pastoral development in Africa. Intermediate Technology, London

Scoones I (2008) Is pastoralism a viable livelihood option? ID21 Insights $72: 6$

Serageldin I (1996) Sustainability and the wealth of nations, First steps in an ongoing journey. Development Studies and Monographs, Series No. 5. World Bank, Washington

Sheth JN, Parvatiyar A (1995) The evolution of relationship marketing. Int Bus Rev 4:397-418

Slegers M, Stroosnijder L (2008) Beyond the desertification narrative: a framework for agricultural drought in semiarid East Africa. Ambio 37:5

Smet M, Ward D (2005) A comparison of the effects of different rangeland management systems on plant species composition, diversity and vegetation structure in a semi-arid savanna. Afr $\mathbf{J}$ Range Forage Sci 22:59-71

Smit B, Wandel J (2006) Adaptation, adaptive capacity and vulnerability. Glob Environ Chang 16(3):282-292

Smith M, McAllister R (2008) Managing arid zone natural resources in Australia for spatial and temporal variability - an approach from first principles. Rangel J 30:15-27

Solomon T, Snyman HA, Smit GN (2007) Cattle-rangeland management practices and perceptions of pastoralists towards rangeland 
degradation in the Borana zone of southern Ethiopia. J Environ Manag 82:481-494. doi:10.1016/j.jenvman.2006.01.008

Spooner B (1971) Towards a generative model of nomadism. Anthropol Q 44:198-210

Steinfeld H, Wassenaar T, Jutzi S (2006) Livestock production systems in developing countries: status, drivers, trends. Rev Sci Tech Off Int Epiz 25:505-516

Steinfeld H, Mooney HA, Schneider F, Neville LE (2010) Livestock in a changing landscape: volume 1 , drivers, consequences, and responses. Island Press, Washington

Sternberg T (2008) Environmental challenges in Mongolia's dry land pastoral landscape. J Arid Environ 72:1294-1304. doi:10.1016/j. jaridenv.2007.12.016

Sullivan S (1999) The impacts of people and livestock on topographically diverse open wood and shrub lands in arid north-west Namibia. Glob Ecol Biogeogr Lett 8:257-277

Sullivan S, Rohde R (2002) On non-equilibrium in arid and semi arid grazing systems. J Biogeogr 29:1-26. doi:10.1046/j.1365-2699. 2002.00799.x

Swift J. (2011) Katherine Homewood: Ecology of African pastoralism. Pastoralism: research, policy and practice, 1-5. doi:10.1156/20417136-1-5

Szymanski DM, Henard DH (2001) Customer satisfaction: a metaanalysis of the empirical evidence. J Acad Mark Sci 29:16-35

Tessema W.K. (2012) Marketing's contribution to the sustainability of pastoralism: Evidence from Ethiopia. Dissertation, Wageningen University, the Netherlands. ISBN: 978-94-6173-314-6

Thornes J (2007) Modelling soil erosion by grazing: recent developments and new approaches. Geogr Res 45:13-26

Thornton PK, Burnsilver SB, Boone RB, Galvin KA (2006) Modelling the impacts of group ranch subdivision on households in Kajiado, Kenya. Agric Syst 87:331-356. doi:10.1016/j.agsy.2005.03.001

Thornton PK, Boone RB, Galvin KA, BurnSilver SB, Waithaka MM, Kuyiah J, Karanja S, González-Estrada E, Herrero M (2007) Coping strategies in livestock-dependent households in east and southern Africa: a synthesis of four case studies. Hum Ecol 35:461-476

Thornton PK, van de Steeg J, Notenbaert A, Herrero M (2009) The impacts of climate change on livestock and livestock systems in developing countries: a review of what we know and what we need to know. Agric Syst 101:113-127. doi:10.1016/j.agsy.2009.05.002

Thorp R, Stewart F, Heyer A (2005) When and how far is group formation a route out of chronic poverty? World Dev 33:907-920

Timmer CP (1997) Farmers and markets: the political economy of new paradigms. Am J Agric Econ 79:621-627

Toulmin C. (1994) Tracking through drought: Options for destocking and restocking. In: Scoones I. (Ed.), Living with uncertainty. Living with uncertainty: New directions in pastoral development in Africa. Intermediate Technology

Turner MD, Hiernaux P (2008) Changing access to labor, pastures, and knowledge: the extensification of grazing management in SudanoSahelian West Africa. Hum Ecol 36:59-80. doi:10.1007/ s10745-007-9149-y

Turner M, Williams T (2002) Livestock market dynamics and local vulnerabilities in the Sahel. World Dev 30:683-705

Turner B, Eric F, Anette R (2007) The emergence of land change science for global environmental change and sustainability. PNAS 104:20666-20671
Tyler NJ, Turi JM, Sundset M et al (2007) Saami reindeer pastoralism under climate change: applying a generalized framework for vulnerability studies to a subarctic social ecological system. Glob Environ Chang 17:191-206. doi:10.1016/j.gloenvcha.2006.06.001

Unruh J (2005) Changing conflict resolution institutions in the Ethiopian pastoral commons: the role of armed confrontation in rule making. GeoJournal 64:225-237. doi:10.1007/s10708-005-5650-2

Upton C (2008) Social capital, collective action and group formation: developmental trajectories in post-socialist Mongolia. Hum Ecol 36:175-188

Verbeke W, D'Haese M, Kyeyamwa H, Opuda-Asibo J, Van Huylenbroeck G (2009) Assessing institutional development for livestock market participation of traditional cattle keepers in Uganda, Tanzania and Kenya. Outlook Agric 38:275-283

Verlinden A, Kruger A (2007) Changing grazing systems in central north Namibia. Land degrad develop 18:179-197. doi:10.1002/ldr.769

Vetter S (2005) Rangelands at equilibrium and non-equilibrium: recent developments in the debate. J Arid Environ 62:321-341. doi:10. 1016/j.jaridenv.2004.11.015

Vetter S, Goqwana WM, Bond WJ, Trollope W (2006) Effects of land tenure, geology and topography on vegetation and soils of two grassland types in South Africa. Afr J Range Forage Sci 23:13-27

von Braun J (1995) Agricultural commercialization: impacts on income and nutritional and implications for policy. Food Policy 20:187202

Wangui E (2008) Development interventions, changing livelihoods, and the making of female Maasai pastoralists. Agric Hum Values 25:365-378

Warren A (1995) Changing understandings of African pastoralism and the nature of environmental paradigms. Trans Inst $\mathrm{Br}$ Geogr 20:193-203

Warren A (2005) The policy implications of Sahelian change. J Arid Environ 63:660-670

Wessels KJ, Prince AS, Carroll M, Malherbe J (2007) Relevance of rangeland degradation in semiarid northeastern South Africa to the non-equilibrium theory. Ecol Appl 17:815-827

Widstrand C (1975) The rationale of nomad economy. Ambio 4:146-153

WISP (2008) Forgotten services, diminished goods: understanding the agroecosystem of pastoralism. WISP Policy Note No. 8

Wurzinger M, Ndumu D, Okeyo A, Sölkner J (2008) Lifestyle and herding practices of Bahima pastoralists in Uganda. Afr J Agric Res 3:542-548

Xiaogang S (2005) Dynamics of continuity and change in pastoral subsistence among the Rendille in northern Kenya: with special reference to livestock management and responses to socioeconomic change. Afr Study Monogr 31:1-94

Yang X, Longjun C, Xinshi Z (2008) Dryland characteristics and its optimized eco-productive paradigms for sustainable development in China. Nat Res Forum 32:215-227. doi:10.1111/j.1477-8947. 2008.00201.x

Yi S, Wu N, Luo P, Wang Q, Shi F, Zhang Q, Ma J (2008) Agricultural heritage in disintegration: trends of agropastoral transhumance on the southeast Tibetan Plateau. Intern J Sust Devt World Ecol $15: 273-282$

Zander KK (2011) Attitudes of livestock keepers to breeding strategies: threats and opportunities for on-farm conservation of the Borana cattle breed. J Agric Sci 3:3-12

Zhang MD, Borjigin EB, Zhang H (2007) Mongolian nomadic culture and ecological culture: on the ecological reconstruction in the agro-pastoral mosaic zone in Northern China. Ecol Econ 62:19-26 